LBNL-47149

\title{
Measured Energy Savings and Demand Reduction from a Reflective Roof Membrane on a Large Retail Store in Austin
}

\author{
S. Konopacki and H. Akbari \\ Heat Island Group \\ Energy Analysis Department \\ Environmental Energy Technologies Division \\ Lawrence Berkeley National Laboratory \\ Berkeley, CA 94720
}

June 2001

This work was supported by the US Environmental Protection Agency (EPA) and the Assistant Secretary for Energy Efficiency and Renewable Energy, Building Technologies, of the US Department of Energy (DOE) under contract No. DE-AC03-76SFOO098. 


\section{Acknowledgement}

This work was supported by the US Environmental Protection Agency (EPA) and the Assistant Secretary for Energy Efficiency and Renewable Energy, Building Technologies, of the US Department of Energy (DOE) under contract No. DE-AC03-76SFOO098. The authors would like to thank Ernst Worrell and Mel Pomerantz (LBNL), Niko Dietsch and Rachel Schmeltz (EPA), Kevin Foley (Sarnafil), and the manager of roofing services (building owner) for their prepublication reviews of this manuscript, also, Leo Rainer (Davis Energy Group) for installation of the monitoring equipment and albedo measurements. 


\section{Executive Summary}

A reflective roof is typically light in color and absorbs less sunlight than a conventional dark-colored roof. Less absorbed sunlight means a lower surface temperature, which directly reduces heat gain through the roof and air-conditioning $(\mathrm{a} / \mathrm{c})$ demand. Thus, reflective roofs reduce $a / c$ energy use, the degree to which primarily depends upon building type, level of roof insulation, plenum ventilation, $a / c$ size and efficiency, and of course, roof albedo. '

\section{Literature Review}

Several field studies have documented measured air-conditioning summertime energy savings and demand reduction from implementation of a reflective roof on residential, office, retail and school buildings. The body of work mostly conducted throughout California and Florida includes: Akbari et al. (1997) Akbari and Rainer (2000) Akridge (1998) Boutwell and Salinas (1986) Hildebrandt et al. (1998) Konopacki et al. (1998) and Parker et al. (1997, 1998a, 1998b \& 1999). The roof-area weighted average of all a/c summertime daily energy savings measured in the California, Florida and Georgia field-study buildings (mix of residential and commercial) was $3.2 \mathrm{Wh} / \mathrm{ft}^{2}$ and the reduced demand was $0.26 \mathrm{~W} / \mathrm{ft}^{2}$. Savings in the hot and dry climate of California ranged from 0.4 to $6.3 \mathrm{Wh} / \mathrm{ft}^{2}$ in energy and 0.15 to 0.63 $\mathrm{W} / \mathrm{ft}^{2}$ in demand for the mostly commercial buildings. Savings in the hot and humid climate of Florida ranged from 0.5 to $12.7 \mathrm{Wh} / \mathrm{ft}^{2}$ in energy and 0.06 to $0.72 \mathrm{~W} / \mathrm{ft}^{2}$ in demand for the mostly residential buildings.

\section{Project Objective and Methodology}

The objective of this project was to measure and document air-conditioning energy savings and demand reduction from a reflective roof membrane retrofit on a large retail store (of a major American retailer) in Austin, Texas. A methodology was devised that incorporated the following five elements.

1. Identify a building with significant potential for a/c energy savings from a reflective roof. The large retail store in Austin was selected for this monitoring project for two reasons. First, the building was scheduled to have the original black rubber roof membrane, of 13 years, replaced with a white thermoplastic membrane. Second, it was identified as a building with significant potential for a/c energy savings from a reflective roof; the white membrane, with such a large increase in solar reflectance compared to black ( $83 \%$ to $5 \%$ ), the tight plenum, the moderate level of roof insulation (R-12hft $\left.{ }^{2 \circ} \mathrm{F} / \mathrm{Btu}\right)$, low efficiency air-conditioning equipment rated at 8.6 EER (2.5 COP), seven days per week operation (9am to 9pin CST) and large conditioned roof area, $100,000 \mathrm{ft}^{2}\left(9300 \mathrm{~m}^{2}\right)$.

2. Instrument building and collect data. Instruments measured the weather conditions on the roof of the building, temperatures inside the building and throughout the roof layers, and air-conditioning and total building power consumption. Data were collected at 15 minute intervals from 26 August 1999 through 30 September 2000; however, due to the membrane replacement, data were not collected from 14 April through 23 May 2000 . Additionally, roof solar reflectance was measured along the membrane before the retrofit.

3. Analyze data and develop statistical model. Prepared domains from August and September data for pre- and post-retrofit periods and identified air-conditioning energy use and demand as a function of the outdoor-indoor air temperature difference in those domains.

4. Calculate air-conditioning daily energy savings and demand reduction. Contrasted the pre- and post-retrofit summertime energy use and demand utilizing the statistical model to estimate impact of the reflective membrane.

I Albedo is the solar reflectance of a material. It is defined as the hemispherical reflectivity integrated over the solar spectrum (albedo=reflectance $=1$-absorptance). 
5. Cost-benefit analysis. Calculated the abated annual energy and demand expenditures, simple payback period and present value of future savings over the base-line service life of the roof membrane.

\section{Reflective Roof Benefits}

There are numerous benefits from the reflective roof membrane retrofit on this large retail store in Austin, Texas. Direct benefits include air-conditioning daily energy savings, a/c demand reduction, $a / c$ annual abated energy and demand expenditures and present value of future savings. Benefits were calculated for the months of August and September and are highlighted below for the $100,000 \mathrm{ft}^{2}\left(9300 \mathrm{~m}^{2}\right)$ building.

1. A/C average summertime daily energy savings of $355 \mathrm{kWh}, 3.6 \mathrm{Wh} / \mathrm{ft}^{2}\left(39 \mathrm{Wh} / \mathrm{m}^{2}\right), 11 \%$ or $\$ 25$.

2. A/C average summertime demand (1-4pm) was reduced by $35 \mathrm{~kW}, 0.35 \mathrm{~W} / \mathrm{tt}^{2}\left(3.8 \mathrm{~W} / \mathrm{m}^{2}\right), 14 \%$ or $\$ 490 /$ month.

3. A/C annual abated energy expenditures were $\$ 4400$ (63MWh) and for demand they were $\$ 2800\left(200 \mathrm{~kW}\right.$, totaling $\$ 7200$ or $7.2 d / \mathrm{ft}^{2}\left(77 \not / \mathrm{m}^{2}\right)$. Note, this estimate does not include savings from taxes and other utility charges.

4. Instantaneous payback. Negligible incremental combined labor and material costs from replacing the black rubber membrane with white thermoplastic, where the combined costs for both membranes were about $1.50 \$ / \mathrm{f}^{2}\left(16 \$ / \mathrm{m}^{2}\right)$. Note, this is based on data provided by the building manager.

5. Present value of future abated energy and demand expenditures is estimated to range from $\$ 62,000$ to $\$ 71,000$. Estimated with a real discount rate of $3 \%$, a base-line 13 year membrane service life and an aged white-membrane solar reflectance with $10 \%$ to $20 \%$ degradation from the initial value of 0.83 .

Additional benefits include participation in load curtailment and reflective roof rebate programs, and a decrease in roof surface and plenum air temperatures.

6. Participate in a load curtailment program. Austin Energy offers a Load Cooperative Program (Austin 2000a) which will make incentive payments consisting of two components to the customer for providing curtailable electric power between 1 June and 30 September: [1] Load Reduction Premium of $\$ 1.25 / \mathrm{kW}$ for average delivered $\mathrm{kW}$ of all curtailment sessions that have occurred during that calendar month, [2] Consumption Incentive of $\$ 0.15 / \mathrm{kWh}$ for all delivered $\mathrm{kWh}$ that month. If this retail building was in Austin Energy's Load Cooperative Program, a load reduction premium of $\$ 44$ would be payed for $35 \mathrm{~kW}$ in reduced demand for each curtailable session, and a consumption incentive of about $\$ 6300$ would be payed for saving 42MWh during the four month period.

7. Participate in a reflective roof rebate program. Austin Energy offers a Commercial Rebate Program (Austin 2000b) for reflective roofs. The existing roof must not be a reflective roof and the solar reflectance of the coating or single-ply membrane must have a minimum initial reflectance of $75 \%$. The rebate payment cannot exceed $50 \%$ of the total job cost, which includes equipment, installation and tax. If this retail building was in Austin Energy's Commercial Rebate Program, a maximum rebate on materials and labor of $\$ 0.75 / \mathrm{ft}^{2}$ or $\$ 75,000$ would be issued.

8. Average summertime maximum roof surface temperature decreased from $168^{\circ} \mathrm{F}\left(76^{\circ} \mathrm{C}\right)$ to $126^{\circ} \mathrm{F}\left(52^{\circ} \mathrm{C}\right)$. High temperature conditions accelerate the degradation in resistance of polyisocyanurate insulation, such as those with a black roof membrane. The owner's historical practice is to use more insulation (higher R-value) to compensate for the decrease in R-value, thus the additional layer of insulation is not necessary with a reflective roof.

9. Average summertime maximum plenum air temperature decreased from $101^{\circ} \mathrm{F}\left(38^{\circ} \mathrm{C}\right)$ to $95^{\circ} \mathrm{F}\left(35^{\circ} \mathrm{C}\right)$. Since cables and electrical equipment are typically located in the plenum, the life of cable insulation increases in response to a reduced plenum air temperature. 


\section{Table of Contents}

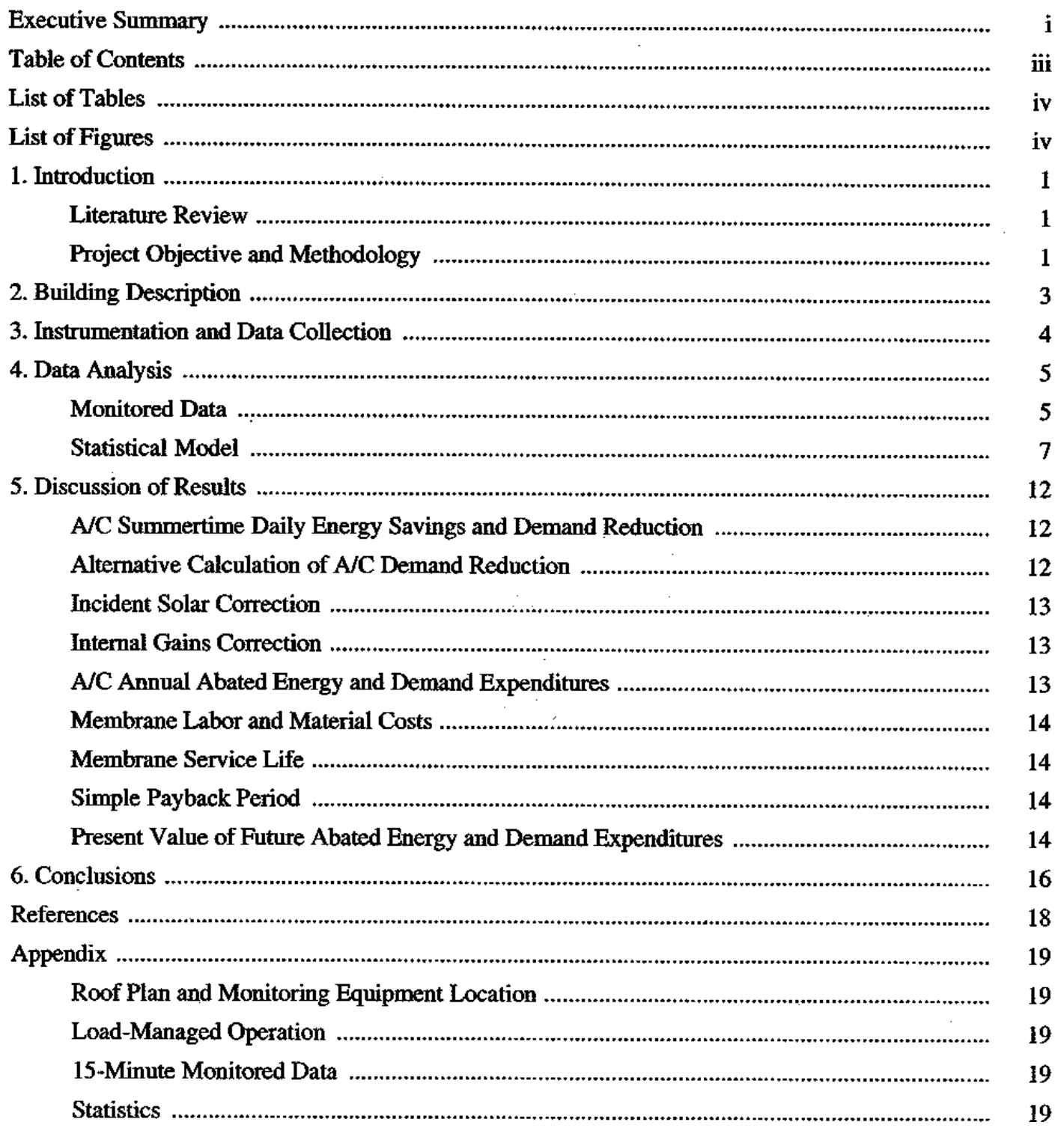




\section{List of Tables}

Table

Description

Table 1.1. Documented field studies of measured summertime air-conditioning

daily energy savings and reduced demand from reflective roofs.

Table 2.1. Building characteristics for the large retail store in Austin, Texas............................ 3

Table 3.1. Monitored parameters and instrumentation used. .....................................................4 4

Table 4.1. Single-variable and multi-variate regression coefficients, root mean square error $(\sigma)$ and $\mathrm{R}^{2}$ for daily (hourly) air-conditioning energy use as a function of the average daily (hourly) difference between outdoor and indoor air temperatures for pre- and post-retrofit periods.

Table 5.1. Estimates of summertime daily energy use and savings and hourly demand and reduction from the multi-variate statistical model.

Table A.1. Single-variable regression analysis of variance, coefficients, standard error and uncertainty in model estimates of daily (hourly) air-conditioning energy use versus the daily (hourly) difference between the outdoor and indoor air temperature for pre- and post-retrofit periods.

Table A.2. Multi-variate regression analysis of variance, coefficients, standard error, model estimates and uncertainty of daily (hourly) ait-conditioning energy use versus the daily (hourly) difference between the outdoor and indoor air temperature for pre- and post-retrofit periods.

\section{List of Figures}

Figure

Description

Figure 4.1. Average daily profiles by hour for pre- and post-retrofit periods. 6

Figure 4.2. Scatter plot of daily a/c electricity nse versus average daily outdoor-indoor temperature difference for pre- and post-retrofit periods. 9

Figure 4.3. Scatter plots of hourly a/c electricity use versus average hourly outdoor-indoor temperature difference for pre- and post-retrofit periods.

Figure A.1. Roof plan identifies location of monitoring equipment and air-conditioning units.

Figure A.2. Monitored 15-minute indoor air temperature and air-conditioning power consumption data for the post-retrofit period of 30-31 August 2000 features a load-managed and a normal operating day.

Figure A.3. Monitored 15-minute weather data for pre- and post-retrofit periods. 22

Figure A.4. Monitored 15-minute roof system temperature data for pre- and post-retrofit periods.

Figure A.5. Monitored 15-minute power consumption data for pre- and post-retrofif periods. 


\section{Introduction}

A reflective roof is typically light in color and absorbs less sunlight than a conventional dark-colored roof. Less absorbed sunlight means a lower surface temperature, which directly reduces heat gain through the roof and air-conditioning (a/c) demand. Thus, reflective roofs reduce $a / c$ energy use, the degree to which primarily depends upon building type, level of roof insulation, plenum ventilation, a/c size and efficiency, and of course, roof albedo. ${ }^{2}$

\section{Literature Review}

Several field studies have documented measured air-conditioning summertime energy savings and demand reduction from implementation of a reflective roof. Results of these studies are highlighted in Table 1.1. Konopacki et al. (1998) have demonstrated the impact of reflective roofs in three California commercial buildings, two medical office and one retail store, summertime daily air-conditioning savings of $6.3,3.6$ and $0.4 \mathrm{Wh} / \mathrm{ft}^{2}(18 \%, 13 \%$ and $2 \%)$ and reduced demand of $0.31,0.22$ and $0.15 \mathrm{~W} / \mathrm{ft}^{2}(12 \%$, $8 \%$ and $9 \%$ ). Akbari et al. (1997) have shown in one monitored Sacramento house summertime daily cooling energy savings of $1.3 \mathrm{Wh} / \mathrm{ft}^{2}(63 \%)$ and peak power reduction of $0.33 \mathrm{~W} / \mathrm{ft}^{2}(25 \%)$, and in a Sacramento school bungalow, cooling energy savings of $4.4 \mathrm{Wh} / \mathrm{ft}^{2}(46 \%$ ) and peak power reduction of $0.63 \mathrm{~W} / \mathrm{ft}^{2}(20 \%)$ from an increase in roof reflectance. Hildebrandt et al. (1998) measured daily a/c savings of $0.9,1.9$ and $1.0 \mathrm{Wh} / \mathrm{ft}^{2}(17 \%, 26 \%$ and $39 \%)$ in an office, museum and hospice with reflective roofs in Sacramento. Parker et al. (1998a) have monitored the performance of reflective roofs in eleven Florida residences with daily savings ranging from 0.5 to $12.7 \mathrm{Wh} / \mathrm{ft}^{2}(2 \%-43 \%)$ and peak demand reduction of 0.14 to $0.72 \mathrm{~W} / \mathrm{ft}^{2}(12 \%-28 \%$ ). Parker et al. (1999) measured daily energy savings of $17 \%$ from a reflective roof in a high-efficiency home in Florida. Parker et al. (1997) have also monitored seven retail stores within a strip mall in Florida before and after applying a reflective roof coating and measured a 0.7 $\mathrm{Wh} / \mathrm{ft}^{2}$ (25\%) drop in summertime daily cooling energy use and a $0.06 \mathrm{~W} / \mathrm{ft}^{2}(29 \%)$ decrease in demand. Parker et al. (1998b) measured daily energy savings of $4.1 \mathrm{Wh} / \mathrm{ft}^{2}(25 \%)$ and peak power reduction of $0.56 \mathrm{~W} / \mathrm{ft}^{2}(30 \%)$ from a reflective roof on a school building in Florida. Akridge (1998) reported daily savings of $7.0 \mathrm{Wh} / \mathrm{ft}^{2}$ (28\%) for an education building in Georgia which had an unpainted galvanized roof coated with white acrylic. An office building in southern Mississippi was shown to save $22 \%$ after the application of a reflective roof coating (Boutwell and Salinas 1986). Akbari and Rainer (2000) measured daily a/c energy savings of $3.1 \mathrm{Wh} / \mathrm{ft}^{2}(1 \%)$ in two Nevada telecommunication regeneration buildings.

The roof-area weighted average of all a/c summertime daily energy savings measured in the California, Florida and Georgia field-study buildings (mix of residential and commercial) was $3.2 \mathrm{Wh} / \mathrm{ft}^{2}$ and the reduced demand was $0.26 \mathrm{~W} / \mathrm{ft}^{2}$. Savings in the hot and dry climate of Califormia ranged from 0.4 to 6.3 $\mathrm{Wh} / \mathrm{ft}^{2}$ in energy and 0.15 to $0.63 \mathrm{~W} / \mathrm{ft}^{2}$ in demand for the mostly commercial buildings. Savings in the hot and humid climate of Florida ranged from 0.5 to $12.7 \mathrm{Wh} / \mathrm{ft}^{2}$ in energy and 0.06 to $0.72 \mathrm{~W} / \mathrm{ft}^{2}$ in demand for the mostly residential buildings.

\section{Project Objective and Methodology}

The objective of this project was to measure and document air-conditioning energy savings and demand reduction from a reflective roof membrane retrofit on a large retail store in Austin, Texas. A methodology was devised that incorporated the following five elements.

1. Identify a building with significant potential for a/c energy savings from a reflective roof. The large retail store in Austin was selected for this monitoring project for two reasons. First, the building was scheduled to have the original black rubber roof membrane, of 13 years, replaced with white thermoplastic. Second, it was identified as a building with significant potential for a/c energy

\footnotetext{
2 Albedo is the solar reflectance of a material. It is defined as the hemispherical reflectivity integrated over the solar spectrum (albedo=reflectance=1-absorptance).
} 
savings from a reflective roof; the white membrane, with such a large increase in solar reflectance compared to black ( $83 \%$ to $5 \%$ ), the tight plenum, the moderate level of roof insulation (R$12 \mathrm{hft}^{2 \circ} \mathrm{F} / \mathrm{Btu}$ ), low efficiency air-conditioning equipment (rated EER at 8.6), seven days per week operation (9am to 9pm CST) and large conditioned roof area $\left(100,000 \mathrm{ft}^{2}\right)$.

2. Instrument building and collect data. Instruments measured the weather conditions on the roof of the building, temperatures inside the building and throughout the roof layers, and air-conditioning and total building power consumption. Additionally, roof solar reflectance was measured along the membrane before the retrofit.

3. Analyze data and develop statistical model. Prepared data domains for pre- and post-retrofit periods and identified air-conditioning energy use and demand as a function of the outdoor-indoor air temperature difference in those domains.

4. Calculate air-conditioning daily energy savings and demand reduction. Contrasted the pre- and post-retrofit energy use and demand utilizing the statistical model to estimate impact of the reflective membrane.

5. Cost-benefit analysis. Calculated the abated annual energy and demand expenditures, simple payback period and present value of future savings over the base-line service life of the roof membrane.

Table 1.1. Documented field studies of measured summertime air-conditioning daily energy savings and reduced demand from reflective roofs ( $\rho$ is solar reflectance and $R B$ is radiant barrier).

\begin{tabular}{|c|c|c|c|c|c|c|c|c|c|}
\hline \multirow{2}{*}{ location } & \multirow{2}{*}{ building type } & \multirow{2}{*}{$\begin{array}{c}\text { roof area } \\
\mathrm{ft}^{2}\end{array}$} & \multicolumn{3}{|c|}{ roof system description } & \multicolumn{2}{|c|}{ daily savings } & \multicolumn{2}{|c|}{ reduced demand } \\
\hline & & & R-val & duct & $\Delta \rho$ & $\mathrm{Wh} / \mathrm{ft}^{2}$ & $\%$ & $w / \mathrm{ft}^{2}$ & $\%$ \\
\hline \multicolumn{10}{|l|}{ California } \\
\hline Davis & medical office & 31700 & 8 & interior & 0.36 & 6.3 & 18 & 0.31 & 12 \\
\hline Gilroy & $n$ & 23800 & 19 & plenum & 0.35 & 3.6 & 13 & 0.22 & 8 \\
\hline San Jose & retail store & 32900 & RB & plenum & 0.44 & 0.4 & 2 & 0.15 & 9 \\
\hline Sacramento & school bnglw & 960 & 19 & ceiling & 0.60 & 4.4 & 46 & 0.63 & 20 \\
\hline Sacramento & residence & 1830 & 11 & crawl & 0.59 & 1.3 & 63 & 0.33 & 25 \\
\hline Sacramento & office & 24600 & 19 & plenum & 0.40 & 0.9 & 17 & $\mathrm{n} / \mathrm{a}$ & - \\
\hline Sacramento & museum & 4900 & 0 & interior & 0.40 & 1.9 & 26 & $\mathbf{n} / \mathbf{a}$ & - \\
\hline Sacramento & hospice & 6000 & 11 & attic & 0.40 & 1.0 & 39 & $n / a$ & - \\
\hline \multicolumn{10}{|l|}{ Florida } \\
\hline Cape Canaveral & residence & 1400 & 11 & attic & $\mathbf{n} / \mathbf{a}$ & 5.4 & 22 & 0.14 & 12 \\
\hline Cocoa Beach & $"$ & 1200 & 0 & attic & 0.63 & 12.7 & 43 & 0.72 & 28 \\
\hline Cocoa Beach & $"$ & 1300 & 0 & attic & 0.39 & 10.8 & 26 & 0.71 & 29 \\
\hline Cocoa Beach & $"$ & 1300 & 11 & attic & 0.52 & 7.9 & 25 & 0.51 & 28 \\
\hline Cocoa Beach & $"$ & 1500 & 19 & attic & 0.42 & 2.9 & 13 & 0.15 & 11 \\
\hline Merritt Island & $"$ & 1700 & 7 & attic & 0.44 & 6.8 & 20 & 0.58 & 23 \\
\hline Merritt Island & $"$ & 1800 & 25 & attic & 0.51 & 2.2 & 11 & $\mathbf{n} / \mathbf{a}$ & - \\
\hline Miami & $"$ & 1400 & 11 & attic & 0.30 & 5.9 & 15 & 0.32 & 16 \\
\hline Palm Bay & $"$ & 1500 & 19 & attic & 0.44 & 2.1 & 10 & 0.24 & 16 \\
\hline Palm Bay & $"$ & 1800 & 19 & attic & 0.42 & 0.5 & 2 & 0.17 & 12 \\
\hline West Florida & " & 900 & 0 & none & 0.53 & 6.2 & 25 & 0.55 & 30 \\
\hline Lakeland & $"$ & 2400 & 30 & attic & 0.65 & $\mathrm{n} / \mathrm{a}$ & 17 & $\mathbf{n} / \mathbf{a}$ & - \\
\hline Cocoa Beach & strip mall & 12500 & 11 & plenum & 0.46 & 0.7 & 25 & 0.06 & 29 \\
\hline Cocoa Beach & school & 10000 & 19 & plenum & 0.46 & 4.1 & 25 & 0.56 & 30 \\
\hline \multicolumn{10}{|l|}{ Georgia } \\
\hline Atlanta & education & 12000 & 11 & plenum & $\mathrm{n} / \mathrm{a}$ & 7.0 & 28 & $\mathbf{n} / \mathrm{a}$ & - \\
\hline $\begin{array}{l}\text { Mississippi } \\
\text { southern }\end{array}$ & & $n / a$ & 11 & & $\pi / 9$ & $\pi / 9$ & 20 & $=$ & \\
\hline Nevada & Dille & Wia & 11 & ilra & wa & IIV & 22 & $10 / d$ & - \\
\hline Reno & regeneration & 160 & 18 & none & 0.39 & 3.1 & 1 & $\mathbf{n} / \mathbf{a}$ & - \\
\hline
\end{tabular}




\section{Building Description}

The building studied in this project was a single-story large retail store in Austin, Texas. It belongs to a major American retailer and has a total floor area of $100,000 \mathrm{ft}^{2}$, all of it conditioned $\left(87,000 \mathrm{ft}^{2}\right.$ of sales with a $13^{\prime}$ ceilings, $10,000 \mathrm{ft}^{2}$ of storage with a $20^{\prime}$ ceilings and $3,000 \mathrm{ft}^{2}$ of office with an $8^{\prime}$ ceiling). Building characteristics are summarized in Table 2.1. The building was constructed in 1987 with an exposed black rubber EPDM (Ethylene Propylene Diene Monomer) roof membrane, and it still has the original HVAC equipment; 16 roof-top package umits and one mini-split. The roof consists of a metal deck covered with 2" of polyisocyanurate foam insulation (R-12hft $\left.{ }^{20} \mathrm{~F} / \mathrm{Btu}\right)$ and the mechanically attached membrane. The sales floor has a dropped $t$-bar ceiling with acoustical tile. The total conductance of the roof system was estimated at $0.062 \mathrm{Btu} / \mathrm{hft}{ }^{2 \circ} \mathrm{F}$. The walls are $6^{\prime \prime}$ wood frame with fiberglass insulation, gypsum board interior and masonry exterior. The floor is slab-on-grade covered with vinyl on the sales floor. The store is operated from 9am to 9pm CST seven days a week and is open on holidays.

This building was selected for two reasons. First, the building was scheduled to have the original exposed black rubber membrane, of 13 years, replaced with a white thermoplastic PVC (PolyVinyl Chloride) exposed roofing system, which is standard practice for the retailer when replacing a roof membrane. Second, it was identified as a building with significant potential for a/c energy savings from a reflective roof; the white membrane, with such a large increase in solar reflectance compared to black ( $83 \%$ to $5 \%$ ), the tight plenum, the moderate level of roof insulation (R-12), low efficiency airconditioning equipment rated at $8.6 \mathrm{EER}(2.5 \mathrm{COP})$, seven days per week operation (9am to 9pm CST) and large conditioned roof area $\left(100,000 \mathrm{ft}^{2}\right)$.

Table 2.1. Building characteristics for the large retail store in Austin, Texas.

\begin{tabular}{|c|c|c|}
\hline type & single-story large retail & $100,000 \mathrm{ft}^{2}$ \\
\hline \multirow[t]{3}{*}{ zones } & sales & $87,000 \mathrm{ft}^{2}$ \\
\hline & office & $3,000 \mathrm{ft}^{2}$ \\
\hline & storage & $10,000 \mathrm{ft}^{2}$ \\
\hline \multirow[t]{3}{*}{ roof construction } & black rubber EPDM membrane & pre-retrofit \\
\hline & $\begin{array}{l}\text { white thermoplastic PVC membrane } \\
\text { metal deck ( } 0^{\circ} \text { slope) }\end{array}$ & post-retrofit \\
\hline & $\begin{array}{l}\text { 2" polyisocyanurate foam insulation } \\
\text { plenum }\end{array}$ & $\mathrm{R}-12 \mathrm{hft}^{2 \circ} \mathrm{F} / \mathrm{Btu}$ \\
\hline \multirow{3}{*}{ roof reflectance } & $\begin{array}{l}\text { dropped t-bar ceiling with acoustical tile } \\
\text { measured pre-retrofit black rubber }\end{array}$ & 0.05 \\
\hline & initial lab measured white thernoplastic & 0.83 \\
\hline & 3-year aged post-retrofit white thermoplastic & 0.75 \\
\hline \multirow[t]{2}{*}{ wall construction } & masonry exterior & \\
\hline & $\begin{array}{l}\text { 6" wood frame } \\
\text { fiberglass insulation } \\
\text { gypsum board interior }\end{array}$ & \\
\hline foundation & slab-on-grade with vinyl in sales area & \\
\hline interior load & non-a/c power $9 \mathrm{am}$ to $6 \mathrm{pm}$ & $1.6 \mathrm{~W} / \mathrm{ft}^{2}$ \\
\hline \multicolumn{3}{|l|}{ air-conditioning equipment } \\
\hline sales perimeter & 7 roof-top package & $178 \mathrm{kBtw} / \mathrm{h}$ \\
\hline sales interior & 7 roof-top package & $180 \mathrm{kBtu} / \mathrm{h}$ \\
\hline office & 2 roof-top package & $48 \mathrm{kBtw} / \mathrm{h}$ \\
\hline storage & 1 mini-split & $24 \mathrm{kBtw} / \mathrm{h}$ \\
\hline rated efficiency & EER (Energy Efficiency Ratio) & $8.6 \mathrm{kBtu} / \mathrm{h} / \mathrm{kW}$ \\
\hline \multicolumn{3}{|l|}{ thermostat setpoint } \\
\hline sales & & $80^{\circ} \mathrm{F}$ \\
\hline office & & $80^{\circ} \mathrm{F}$ \\
\hline storage & & $85^{\circ} \mathrm{F}$ \\
\hline
\end{tabular}




\section{Instrumentation and Data Collection}

Instruments measured the weather conditions on the roof of the building, the temperature profile through the roof system, and total and airzconditioning power consumption. Data were monitored at 15 minute intervals from 26 August 1999 through 30 September 2000 . The weather variables were all measured on a 10' weather tower located at the approximate center of the rooftop, with sensors for outdoor orybulb temperature, outdoor relative humidity, horizontal solar radiation, and wind speed and direction. Multiple sets of roof system temperature measurements were made, with the roof surface, roof underside (beneath insulation), plenum air, and inside air sensors aligned vertically. A power meter and current transformers were attached to the main building and air-conditioning supply panels. The power monitors read three phases of current and voltage, and produce one pulse per $\mathrm{kWh}$. The parameters monitored and instrumentation used in the project are listed in Table 3.1 and the location of the instruments are illustrated on the building roof plan in Figure A.1 in the Appendix.

Instrumentation was wired into a data logger, which was in tum connected to a personal computer with an intemal modem hooked to a phone line. The PC has ProComm Plus for Windows software operating in the background. Every 15 minutes the data logger sent data to the PC. The ProComm Plus software sent these data to two files: an archive file and a file containing all data collected for the previous 168 hours (weekly file). ProComm Plus also maintains a bulletin board in the background, which allows the archive file to be downloaded remotely by calling into the PC.

In addition to the parameters measured by the data logging system, the rooftop solar reflectance was measured in several locations along the roof before the white membrane was installed. These measurements were made using a Kipp \& Zonen CM3 pyranometer (ISO class 2 device) and ASTM Standard 1918-97 (ASTM 1998). The albedo of the original black rubber membrane was measured at 0.05 . The initial albedo of the white membrane measured under laboratory conditions was 0.83 and after application to the roof it can degrade $10 \%$ to $20 \%$ over time, therefore the aged value can range from 0.66 to 0.75 . The difference between the albedo measured initially in the lab and that following the retrofit can be attributed to carbon and dirt collection, the effect of human traffic and irregularities in the roof surface.

Table 3.1. Monitored parameters and instrumentation used.

\begin{tabular}{|c|c|c|}
\hline parameter & number & instrumentation \\
\hline $\begin{array}{l}\text { weather } \\
\text { outdoor drybulb temperature } \\
\text { outdoor relative humidity } \\
\text { horizontal solar radiation } \\
\text { wind speed } \\
\text { wind direction }\end{array}$ & $\begin{array}{l}1 \\
1 \\
1\end{array}$ & $\begin{array}{l}\text { platinum RTD in gill radiation shield } \\
\text { capacitive humidity sensor in } \\
\text { gill radiation shield } \\
\text { silicon photodiode pyranometer } \\
3 \text { cup anemometer } \\
\text { wind vane }\end{array}$ \\
\hline $\begin{array}{l}\text { roof system temperatures } \\
\text { roof surface } \\
\text { roof underside } \\
\text { plenum air } \\
\text { inside air } \\
\text { retum air }\end{array}$ & $\begin{array}{l}3 \\
3 \\
3 \\
3 \\
1\end{array}$ & $\begin{array}{l}\text { platinum RTD } \\
\text { platinum RTD } \\
\text { LM34 semiconductor } \\
\text { LM34 semiconductor } \\
\text { LM34 semiconductor }\end{array}$ \\
\hline $\begin{array}{l}\text { power } \\
\text { total building } \\
\text { air-conditioning }\end{array}$ & $\begin{array}{l}1 \\
1\end{array}$ & $\begin{array}{l}\text { power meter / current transformer } \\
\text { power meter / current transformer }\end{array}$ \\
\hline
\end{tabular}




\section{Data Analysis}

\section{Monitored Data}

Data were collected at 15 minute intervals from 26 August 1999 through 30 September 2000; however, due to the membrane replacement, data were not collected from 14 April through 23 May 2000 . Inspection of the non-air-conditioning end-use load shapes revealed aberrant off-hour building operation from 4 July through 10 August 2000 , thus these data were excluded. Examination of the air-conditioning enduse load shapes and indoor air temperature profiles indicated a load-management strategy was implemented on seemingly random days following the retrofit, these data were also excluded from the analysis (see Figure A.2 in the Appendix for further discussion of load management). The analysis was conducted using the following data domains. For the pre-retrofit period with 36 continuous normal operating days: 26 August through 30 September 1999 , and for the post-retrofit period with 28 non-continuous operating days: 11 August through 30 September 2000. The 15-minute data were then transformed into hourly and daily data sets and average daily profiles by hour were created. All data presented is in central standard time (CST).

Weather data monitored during the pre- and post-data domains were outdoor drybulb temperature, outdoor relative humidity, horizontal solar radiation, and wind speed and direction. The average daily profiles for temperature, humidity and solar are shown in Figure 4.1 and the entire set of 15-minute weather data are in Figure A.3 in the Appendix. The post-conditions were warmer than the pre as indicated in the daily outdoor drybulb temperature profiles averaged over the domains. The profiles show that the average maximum temperature occurred between the $3-4 \mathrm{pm}$ hour reaching nearly $95^{\circ} \mathrm{F}$ in the post period and $91^{\circ} \mathrm{F}$ in the pre-period. Also, solar intensity was higher in the post period by a total of $384 \mathrm{Wh} / \mathrm{m}^{2}$ during hours $12-19$.

Roof system temperature data monitored during the pre- and post-data domains were roof surface, roof underside (beneath insulation), plenum air and indoor air. The average daily profiles are shown in Figure 4.1 and the 15-minute data are in Figure A.4 in the Appendix. The highest recorded roof surface temperature during the pre-period was $200^{\circ} \mathrm{F}$ and $150^{\circ} \mathrm{F}$ in the post, a decrease of $50^{\circ} \mathrm{F}$. Daily roof surface temperature profiles averaged over the domains show that the average maximum occurred between the 1-2pm hour reaching $168^{\circ} \mathrm{F}$ in the pre-period and $126^{\circ} \mathrm{F}$ in the post, a decrease of $42^{\circ} \mathrm{F}$. Daily roof underside temperature profiles (for the two sales zone sensors) averaged over the domains show that the average maximum occurred between the $2-3 \mathrm{pm}$ hour reaching $104^{\circ} \mathrm{F}$ in the pre-period and only $95^{\circ} \mathrm{F}$ in the post, a decrease of $9^{\circ} \mathrm{F}$. Daily plenum air temperature profiles (for the two sales zone sensors) averaged over the domains show that the average maximum occurred between the 2-3pm hour reaching $101^{\circ} \mathrm{F}$ in the pre-period and only $95^{\circ} \mathrm{F}$ in the post, a decrease of $6^{\circ} \mathrm{F}$. Daily indoor air temperature profiles (for the two sales zone sensors) averaged over the domains show the temperature was maintained between $79^{\circ} \mathrm{F}$ and $80^{\circ} \mathrm{F}$ during operating hours in both periods, and the storage zone was kept about $85^{\circ} \mathrm{F}$.

Air-conditioning $(\mathrm{a} / \mathrm{c})$, non-a/c and total building power consumption data monitored during the pre- and post-data domains are shown in average daily profile form in Figure 4.1 and in 15-minute form in Figure A.5 in the Appendix. The highest recorded a/c demand during either of these periods was $320 \mathrm{~kW}\left(3.2 \mathrm{~W} / \mathrm{ft}^{2}\right)$, non-air-conditioning demand averaged about $150 \mathrm{~kW}\left(1.5 \mathrm{~W} / \mathrm{ft}^{2}\right)$ during daytime hours (non-a/c was slightly higher in the post domain by a total of $35 \mathrm{kWh}$ from hours 9-18), and the total building reached a maximum of $470 \mathrm{~kW}\left(4.7 \mathrm{~W} / \mathrm{ft}^{2}\right)$. Daily a/c load shapes averaged over the domains show that the average maximum demand occurred between the $2-3 \mathrm{pm}$ hour reaching nearly $250 \mathrm{kWh}\left(2.5 \mathrm{~W} / \mathrm{ft}^{2}\right)$ in the pre-period and just over $235 \mathrm{kWh}$ in the post. However, the average outdoor-indoor temperature difference (mostly due to outdoor temperature) was $4^{\circ} \mathrm{F}$ higher during the post period, thus a conrection for it must be made to accurately assess a/c energy savings and demand reduction. 
$-6-$

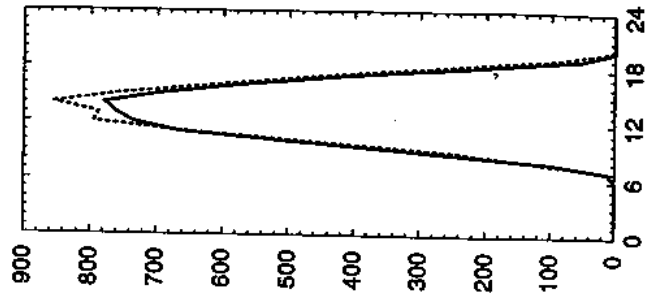

[ubs/M] uo!ze!pen delos [equoz!nou

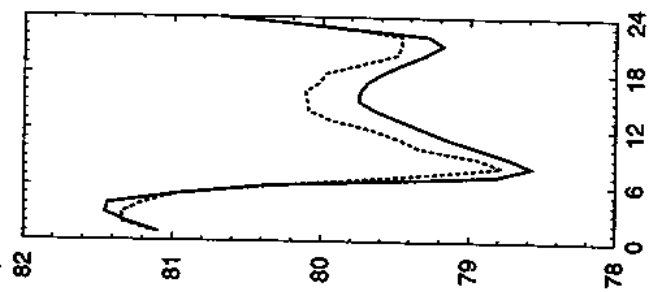

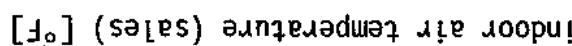

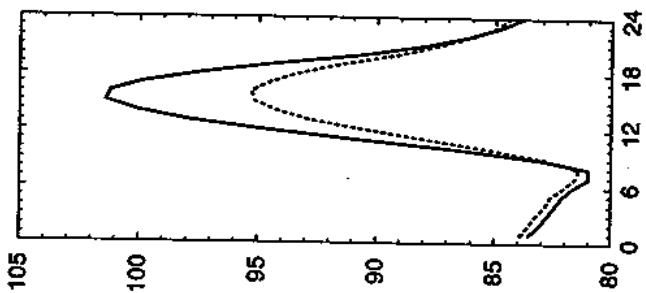

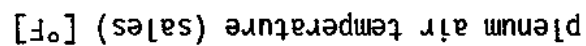

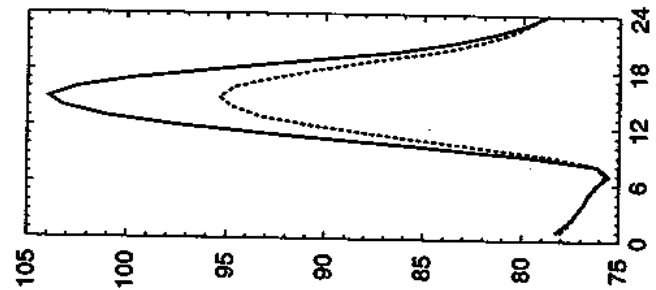

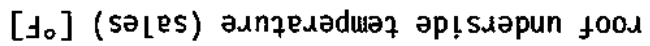

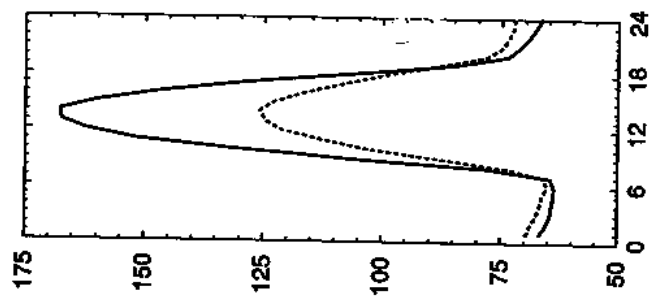

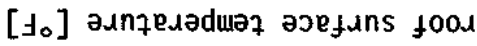

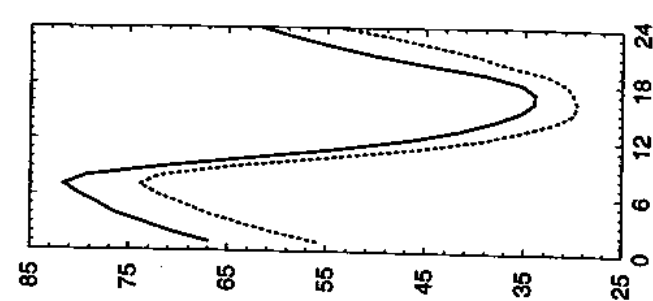

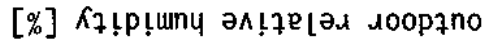

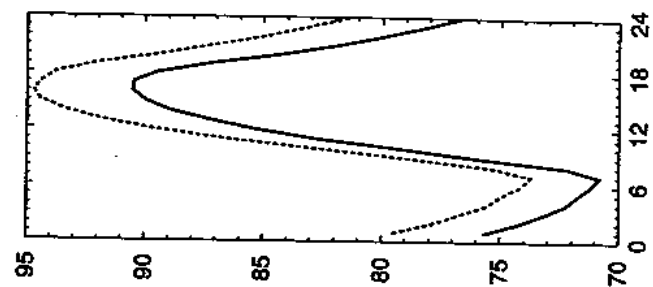

[与。] วunzesəduəz ג!̣e soopqno

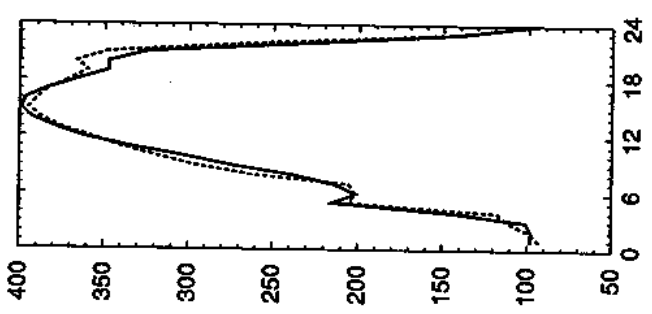

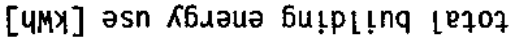

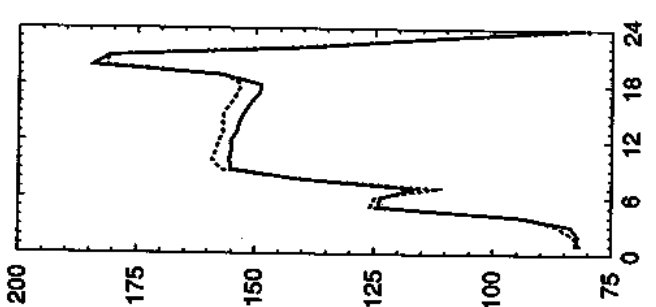

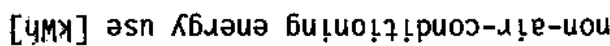

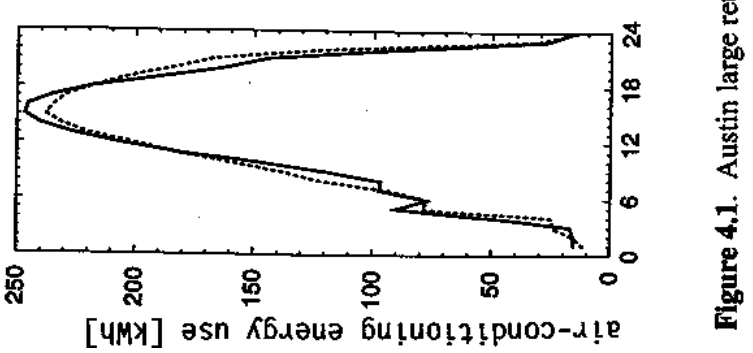




\section{Statistical Model}

A rigorous statistical analysis was conducted under the objective to determine average daily and hourly air-conditioning $(\mathrm{a} / \mathrm{c})$ energy use, and to normalize pre- and post-conditions for the purpose of comparison. To begin, a regression analysis concluded that a/c energy use $\left(\mathrm{kWh}_{\mathrm{a} / \mathrm{c}}\right)$ was a strong function of the difference in outdoor $\left(T_{\text {out }}\right)$ and indoor sales zone $\left(T_{\text {in }}\right)$ air temperatures for both dark and reflective roof conditions, equation 1.

$$
k W h_{a / c}=f\left(T_{\text {out }}-T_{\text {in }}\right)
$$

This function has been employed in a recent reflective roof retrofit study by Akbari and Rainer (2000) and in a modified form in two others (Akbari et. al. 1993 \& Konopacki and Akbari 1998), in the latter studies $\mathrm{kWh}_{\mathrm{a} / \mathrm{c}}$ was solely a function of $\mathrm{T}_{\text {out }}$

Next, a simplified energy balance was written for the building assuming the following: (1) steadystate conditions (2) constant internal gains and scheduling (3) constant incident sunlight for similar preand post-periods (4) constant UA, i.e., no changes to the building shell (5) negligible infiltration (6) constant $\mathrm{a} / \mathrm{c}$ operation and efficiency. The net heat gain into the building was described as the integrated sum (integrated over the day or by hour) of the internal gains, the absorbed solar gains, and the energy conducted through the building shell. The energy balance takes the form of equation 2 .

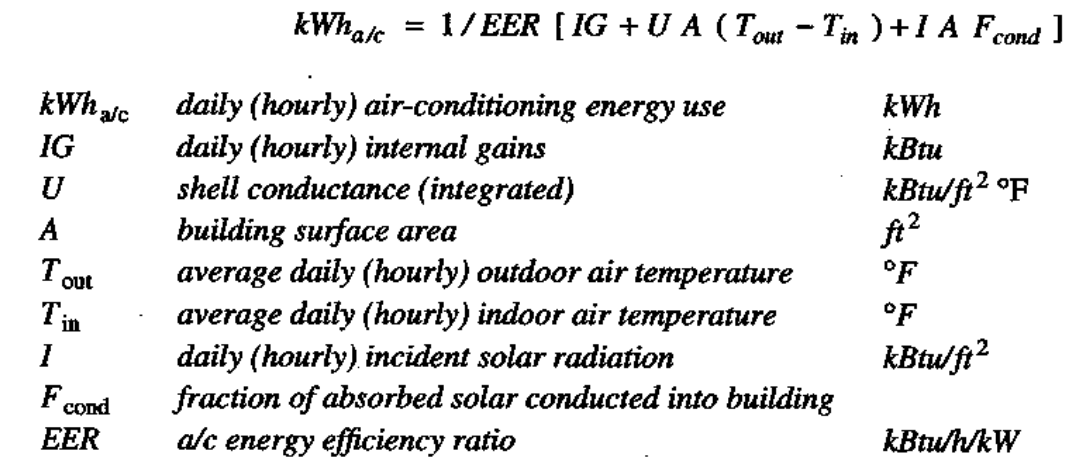

Third, multi-variable regressions were performed with daily and hourly air-conditioning energy use as a function of the difference in outdoor and indoor air temperatures and incident sunlight as in equation 3.

\begin{tabular}{lll}
\multicolumn{3}{c}{$k W h_{a / c}=C_{0}+C_{1}\left(T_{o u t}-T_{i n}\right)+C_{2} I$} \\
$k W h_{\mathrm{a} / \mathrm{c}}$ & daily (hourly) air-conditioning energy use & $k W h$ \\
$l$ & daily (hourly) incident solar radiation on the roof & $k W h$ \\
$T_{\text {out }}$ & average daily (hourly) outdoor air temperature & ${ }^{\circ} \mathrm{F}$ \\
$T_{\text {in }}$ & average daily (hourly) indoor air temperature & ${ }^{\circ} \mathrm{F}$ \\
$C_{0}$ & constant a/c energy use & $k W h$ \\
$C_{1}$ & a/c energy use due to building envelope & $k W h / F$ \\
$C_{2}$ & a/c energy use due to sunlight & $k W h / k W h$
\end{tabular}

This procedure was performed to test the relative significance of $\mathrm{C}_{1}$ and $\mathrm{C}_{2}$. Analysis of the two-tailed significance probability (i.e. the $T$ statistic) indicated that the coefficient $\mathrm{C}_{2}$ was statistically insignificant when compared to $\mathrm{C}_{1}$. The probability under the null hypothesis of obtaining an absolute value of $T$ greater than the $T$ value observed in this sample was 1 in 10,000 for $\mathrm{C}_{1}$ (daily pre- and post-samples) and 1021 in 10,000 for $C_{2, p r e}$ and 455 for $C_{2, p o s r}$. It was concluded that the explicit inclusion of sunlight or $C_{2}$ in the model would not improve the correlation, and thus, $\mathrm{C}_{2}$ was combined with $\mathrm{C}_{0}$. 
In the fourth step, the single-variable statistical model, shown in equation 4 , was analyzed for both daily and hourly domains.

$$
k W h_{a / c}(i)=C_{0}(i)+C_{1}(i)\left(T_{\text {out }}(i)-T_{\text {in }}(i)\right)
$$

$\begin{array}{lll}k W h_{\text {acc }}(\mathrm{i}) & \text { daily (hourly) air-conditioning energy use during period } i & k W h \\ T_{\text {out }}(\mathbf{i}) & \text { average daily (hourly) outdoor air temperature during period } i & { }^{\circ} \mathrm{F} \\ T_{\mathrm{in}}(\mathrm{i}) & \text { average daily (hourly) indoor air temperature during period } i & { }^{\circ} \mathrm{F} \\ C_{0} & \text { constant a/c energy use } & k W h \\ C_{1} & \text { temperanure dependent a/c energy use } & k W h / F \\ i & \text { for pre-period }=l\left(\rho_{\text {low }}\right) \text { and for post-period }=2\left(\rho_{\text {high }}\right) & \end{array}$

Scatter plots of daily (hourly) a/c energy use versus average daily (hourly) difference between the outdoor and indoor air temperatures for both pre- and post-retrofit periods are seen in Figure 4.2 for daily and Figure 4.3 for hourly (hours $10-21$ are $9 \mathrm{am}-9 \mathrm{pm}$ CST). The figures draw attention to two groups of data (dark circles are pre-retrofit and white are for the reflective roof) and provide conclusive visual evidence that this building with a reflective roof uses less a/c energy than with a non-reflective roof.

The single-variable regression results are displayed in Table 4.1, which shows the coefficients $\left(\mathrm{C}_{0}\right.$ and $C_{1}$ ), the root mean square error $(\sigma)$ and $R^{2}$ for the model. The daily pre-retrofit coefficients, $C_{0}$ and $C_{1}$, are targer than of the post conditions, and both correlations have high $R^{2}(0.93$ and 0.97$)$. An hour-by hour comparison of hours 11 through 21 reveal pre-retrofit coefficients that are mostly higher than the post, also $\mathrm{R}^{2}$ are high for these hours. Also, daily $\mathrm{R}^{2}$ were higher than the hourly (except for two hours), and a higher $\mathrm{R}^{2}$ indicates a better correlation. Two parameters can explain why the hourly predictions were less conclusive. The first is thermal storage within the building mass, which creates a delay between the time the outdoor temperature begins to drive the heat through the structure and the hour $a / c$ is required to meet that load. The second is from the effect a/c on-off cycling, where operation in some hour may influence the cycling in the next hour. The analysis of variance, coefficients, standard error and uncertainty from this model are shown in Table A.1 in the Appendix for the daily and hourly data.

In the fifth and final step of the statistical analysis, a multi-variate model was created. It is defined as a single-variable model with two sets of observations, and forces a single slope $\left(\mathrm{C}_{1}\right)$ for both pre- and post-retrofit data, see equation 5.

$$
k W h_{a / c}(i)=\sum_{j=1}^{j=2} C_{0}(j) \delta_{i j}+C_{1}(i)\left(T_{o u t}(i)-T_{i n}(i)\right)
$$

$k W h_{\mathrm{a}_{\mathrm{c}}}(\mathrm{i})$
$T_{\text {out }}(\mathrm{i})$
$T_{\text {in }}(\mathrm{i})$
$C_{0}$
$C_{\mathrm{l}}$
$i$
$\delta_{\mathrm{jj}}$

daily (hourly) air-conditioning energy use during period i

$k W h$ average daily (hourly) outdoor air temperature during period $i$ average daily (hourly) indoor air temperature during period $i$

In the multi-variate model, a single-slope eliminates uncertainties in pre- and post-weather conditions and in building operation; all is constant, with the exception of $\mathrm{T}_{\text {out }}, \mathrm{T}_{\mathrm{in}}$ and sunlight absorbed by the roof. Thus, a/c energy savings are captured entirely by the difference in the coefficients $\mathrm{C}_{0, p r e}$ and $\mathrm{C}_{0 \text {,post }}$. The regression results are displayed in Table 4.1, which shows the coefficients $\left(C_{0, p r e}, C_{0, p o s t}\right.$ and $\left.C_{1}\right)$ and the root mean square error $(\sigma)$. $\mathrm{R}^{2}$ for this model is not shown because the authors were of the opinion that 


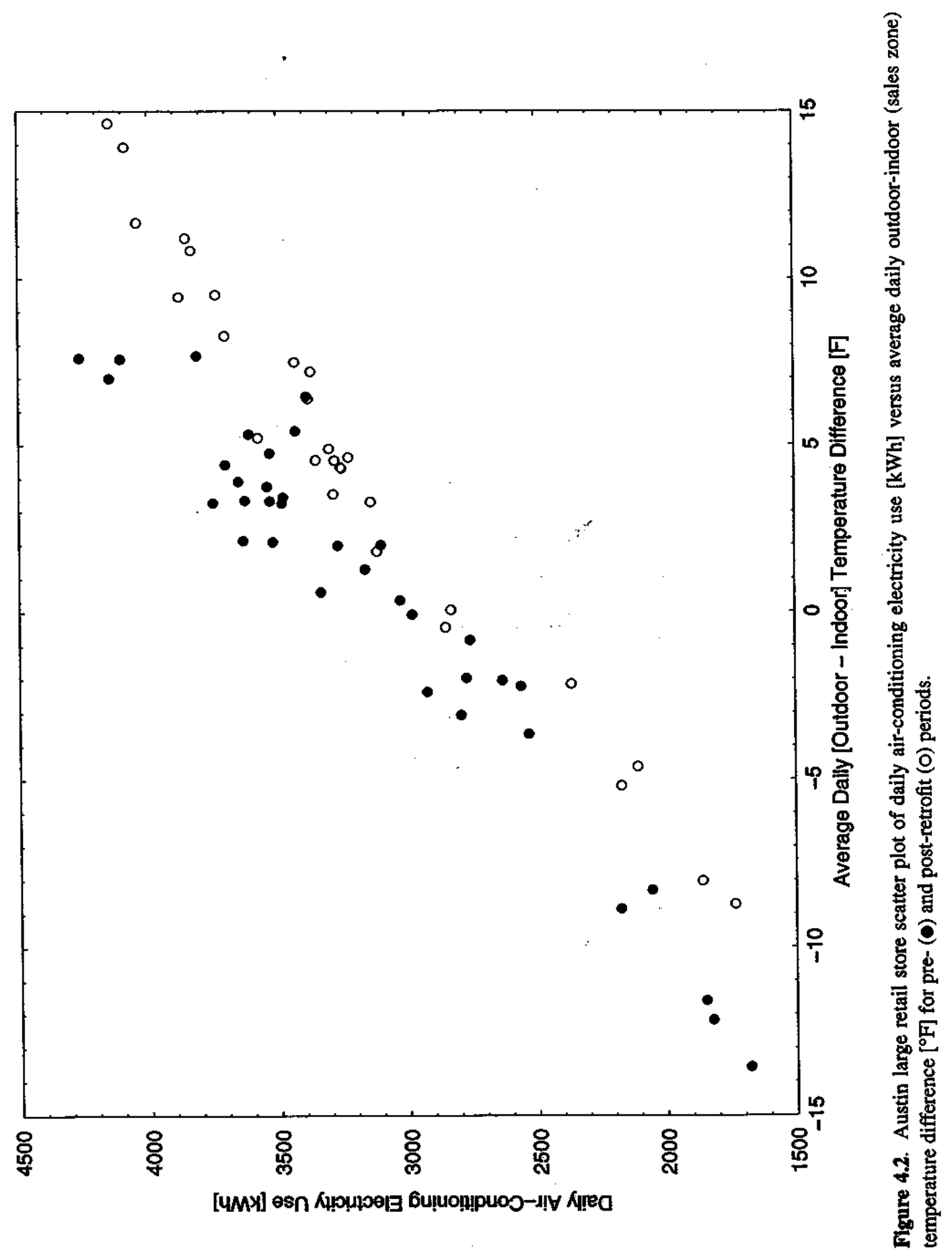



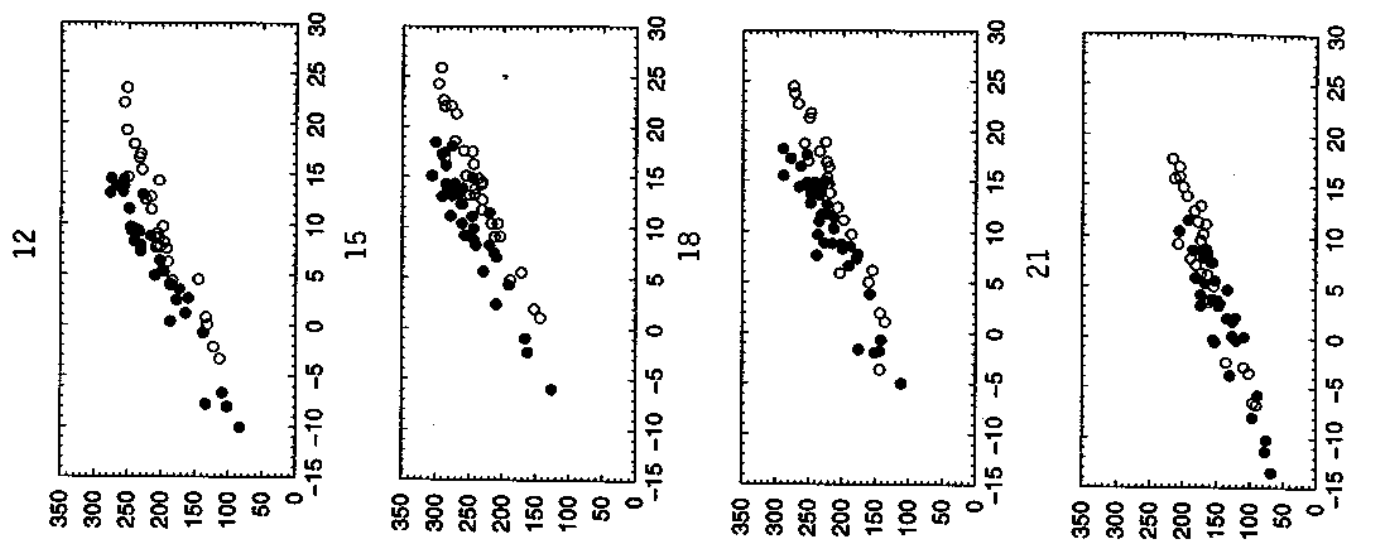

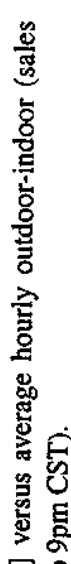
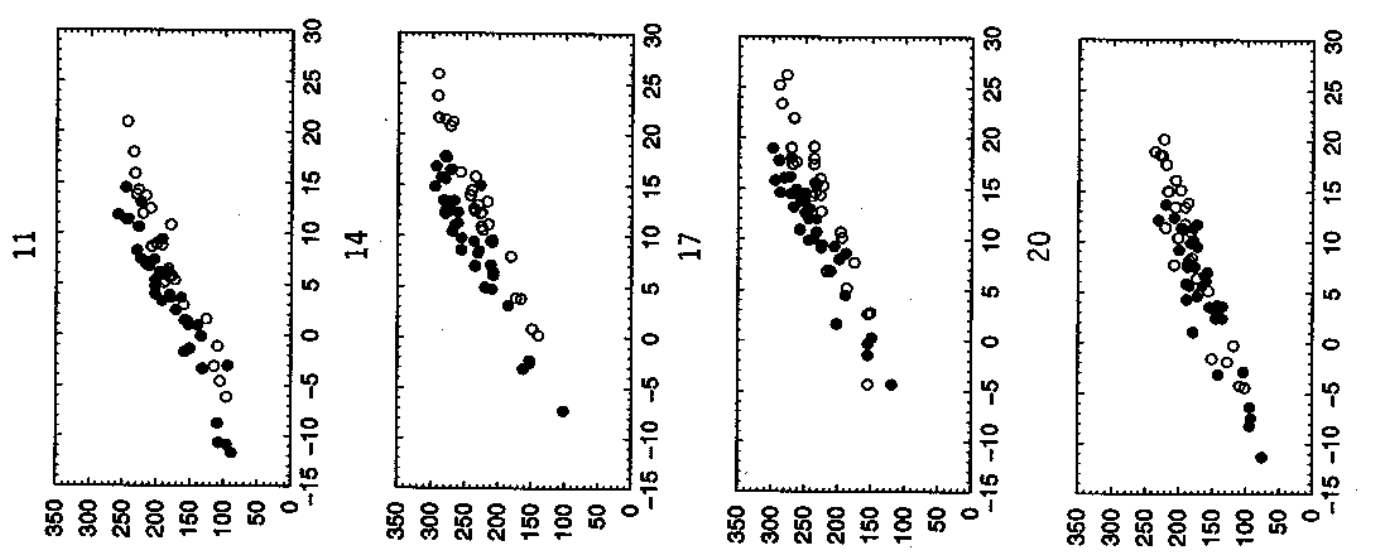

욜
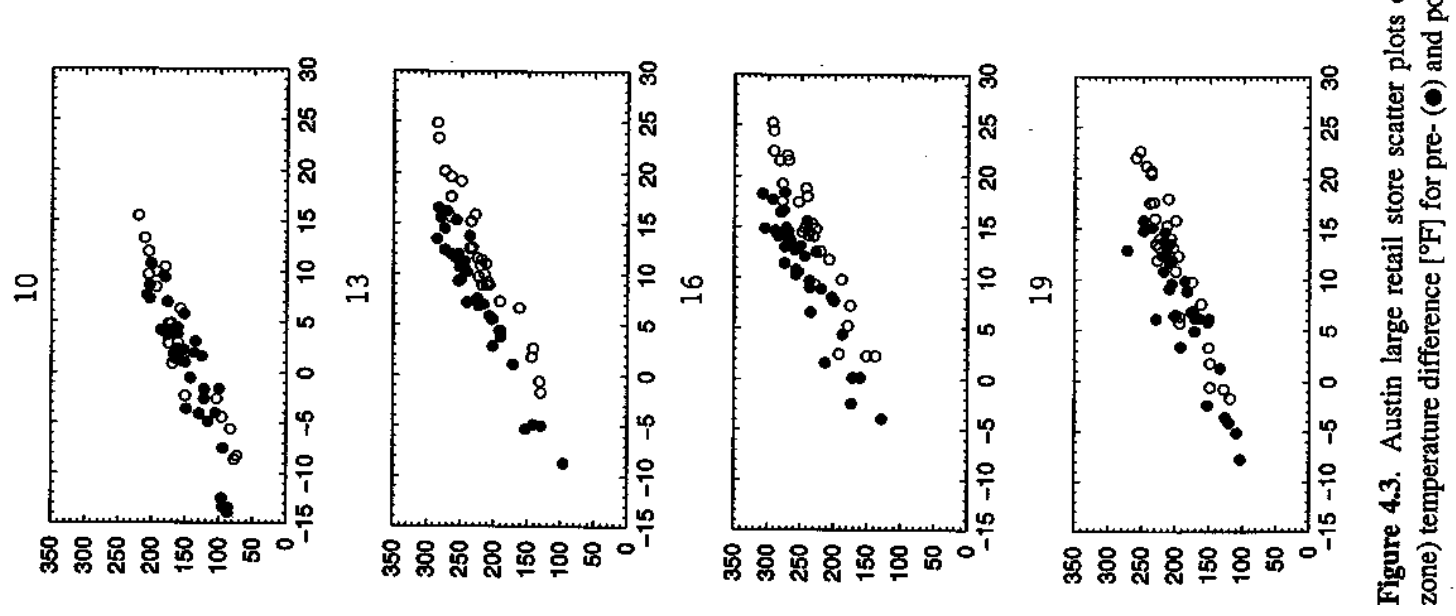
the statistical software used in the analysis was not calculating $\mathbf{R}^{2}$ correctly. The multi-variate daily and hourly $C_{1}$ now fall in between the single-variable regression slopes and the difference in the daily intercepts $\left(C_{0, p r e}-C_{0, p o s t}=355\right)$ is the estimated average daily energy savings in $\mathrm{kWh}$. A look at the hourly coefficients in the table show the $C_{1}$ gradually increase from hours 8 (7-8am) through 14 (1-2pm) and then decrease for the remainder of the day. Also, the $C_{0, p r e}$ coefficients are greater than the $C_{0 \text {,post }}$ for the hours of $10(9-10 \mathrm{am})$ through $21(8-9 \mathrm{pm}$, operation ceases at $9 \mathrm{pm} \mathrm{CST})$. The analysis of variance, coefficients, standard error and uncertainty from these multi-variate regressions are shown in Table A.2 in the Appendix for the daily and hourly data. The regression analysis provides conclusive statistical evidence that this building with a reflective roof uses less a/c energy than with a non-reflective roof.

Table 4.1. Single-variable and multi-variate regression coefficients $\left(C_{0}\right.$ and $\left.C_{1}\right)$, root mean square error $(\sigma)$ and $\mathrm{R}^{2}$ for daily (hourly) air-conditioning energy use [kWh] as a function of the average daily (hourly) difference between outdoor and indoor air temperatures [ $T_{\text {out }}-T_{i n}$ ] for pre- and post-retrofit periods (building operates $9 \mathrm{am}$ to $9 \mathrm{pm}$ CST: hours 10 to 21 ). [Note, $\mathbf{R}^{2}$ for the multi-variate model is not shown because the authors were of the opinion that the statistical software used in the analysis was not calculating $\mathbf{R}^{2}$ correctly].

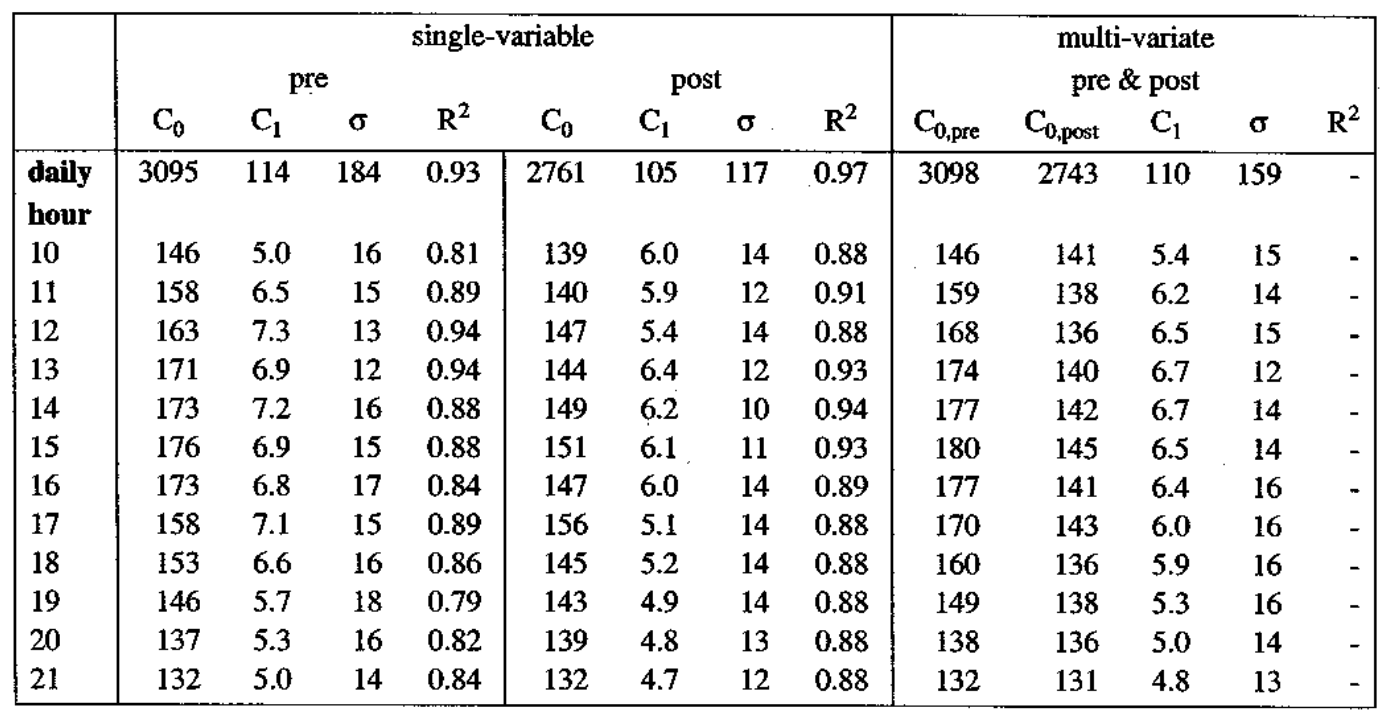




\section{Discussion of Results}

\section{A/C Summertime Daily Energy Savings and Demand Reduction}

Average summertime air-conditioning energy savings and demand reduction were estimated using the multi-variate statistical model. The estimates are shown in Table 5.1 and were drawn from August and September data for pre- (year 1999) and post-retrofit (year 2000) conditions. The daily air-conditioning savings were $355 \mathrm{kWh}\left(3.6 \mathrm{Wh} / \mathrm{ft}^{2}\right.$ or $\left.11 \%\right)$ calculated with an uncertainty of $\pm 41 \mathrm{kWh}$ at $\Delta \mathrm{T}_{\text {mean }}=$ $T_{\text {outmean }}-T_{\text {in,mean }}$. The reduction in demand are calculated and displayed for hours 10 through 21 (9am$9 \mathrm{pm} \mathrm{CST}$ ), since these are the hours which the building operates (note, $\mathrm{kW}$ and $\mathrm{kWh}$ are equivalent for an hourly timestep). The greatest hourly demand reduction occurred within the hours of 14 through 16 (1$4 \mathrm{pm})$ and was $35 \mathrm{~kW}\left(0.35 \mathrm{Wh} / \mathrm{ft}^{2}\right.$ or $\left.14 \%\right)$ calculated with an uncertainty of $\pm 4 \mathrm{~kW}$ at $\Delta \mathrm{T}_{\text {mean. }}$. Note, for hours 10,20 and 21 , the uncertainty in the estimate is near or exceeds the estimate itself, thus the model is valid only for hours 11 to 19 .

Table 5.1. Estimates of summertime daily energy use and savings and hourly demand and reduction from the multi-variate statistical model (uncertainty in $\Delta \mathrm{kWh}$ is indicated with \pm and is calculated at $\left.\Delta \mathrm{T}_{\text {mean }}=\mathrm{T}_{\text {out,mean }}-\mathrm{T}_{\mathrm{in}, \text { mean }}\right)$.

\begin{tabular}{|c|cc|rr|}
\hline & $\mathrm{kWh}_{\text {pre }}$ & $\mathrm{kWh}_{\text {post }}$ & \multicolumn{1}{|c|}{$\Delta \mathrm{kWh}$} & \multicolumn{1}{|c|}{$\Delta \%$} \\
\hline daily & 3343 & 2988 & $355( \pm 41)$ & 11 \\
hour & & & & \\
10 & 156 & 151 & $5( \pm 4)$ & 3 \\
11 & 191 & 170 & $21( \pm 4)$ & 11 \\
12 & 219 & 187 & $32( \pm 4)$ & 15 \\
13 & 238 & 205 & $33( \pm 3)$ & 14 \\
14 & 252 & 217 & $35( \pm 4)$ & 14 \\
15 & 258 & 223 & $35( \pm 4)$ & 14 \\
16 & 256 & 221 & $35( \pm 4)$ & 14 \\
17 & 244 & 217 & $27( \pm 4)$ & 11 \\
18 & 228 & 205 & $23( \pm 4)$ & 10 \\
19 & 201 & 190 & $11( \pm 4)$ & 5 \\
20 & 173 & 171 & $2( \pm 4)$ & 1 \\
21 & 155 & 154 & $1( \pm 3)$ & 1 \\
$1-24$ & 3327 & 3004 & 324 & 10 \\
\hline
\end{tabular}

\section{Alternative Calculation of A/C Demand Reduction}

An alternative calculation for the reduction in air-conditioning demand based on the change in roof surface temperature is presented here to verify the estimate derived from the statistical approach. In this approach, the a/c demand was estimated using the conduction equation (eq. 6) coupled with the same assumptions of the previous section, and the additional assumption of constant indoor air temperature.

$$
k W_{\text {alc }}=U A\left(T_{\text {roof }}-T_{\text {in }}\right) / E E R
$$

\begin{tabular}{lll}
$k W_{\text {alc }}$ & air-conditioning demand & $k W$ \\
$U$ & assumed roof system conductance & $B t u / h \mathrm{ft}^{2}{ }^{\circ} \mathrm{F}$ \\
$A$ & air-conditioned flat roof area & $1000 \mathrm{ft}^{2}$ \\
$T_{\text {roof }}$ & average maximum roof surface temperature & $\circ$ \\
$T_{\text {in }}$ & average indoor air temperature & $\circ$ \\
$E E R$ & assumed a/c energy efficiency ratio & $\mathrm{o}$ \\
\hline
\end{tabular}


In equation 6, all independent parameters are constant except for the average maximum roof surface temperature, which is lower for the reflective roof. Therefore, the savings in a/c demand can be approximated by taking the difference in $\mathrm{kW}$ for pre- and post-conditions, as in equation 7 .

$$
\Delta k W_{a / c}=U A:\left(T_{\text {roof pre }}-T_{\text {roof post }}\right) / E E R
$$

$\begin{array}{lll}\Delta k W_{\mathrm{a} / \mathrm{c}} & \text { air-conditioning demand reduction } & k W \\ T_{\text {roof,pre }} & \text { average maximum roof surface temperature in pre-period } & { }^{\circ} \mathrm{F} \\ T_{\text {roof,post }} & \text { average maximum roof surface temperature in post period } & { }^{\circ} \mathrm{F}\end{array}$

This building has an estimated roof system conductance of 0.062 , a flat roof area of $100,000 \mathrm{ft}^{2}$ over the conditioned space and an assumed a/c energy efficient ratio (EER) of 8 (93\% of the rated value of 8.6 ). The measured average maximum roof surface temperature of the dark membrane was $168^{\circ} \mathrm{F}$ and $126^{\circ} \mathrm{F}$ for the reflective membrane, a decrease of $42^{\circ} \mathrm{F}$. Thus, the reduction in a/c demand is $33 \mathrm{~kW}$ based on this calculation, compared to the estimate of $35 \mathrm{~kW}$ obtained from the statistical analysis.

\section{Incident Solar Correction}

Our model for estimating air-conditioning energy use assumed constant incident sunlight for similar preand post-periods (August and September data), however there was a slight increase in solar radiation during the post-retrofit period of $0.007 \mathrm{kWh} / \mathrm{ft}^{2}\left(75 \mathrm{Wh} / \mathrm{m}^{2}\right)$ around $1-2 \mathrm{pm}$ and $0.036 \mathrm{kWh} / \mathrm{ft}^{2}\left(384 \mathrm{Wh} / \mathrm{m}^{2}\right)$ total for hours 12-19. A correction to estimated a/c demand reduction and daily energy savings for an increase in post-period sunlight of $+9 \mathrm{~kW}$ and $+45 \mathrm{kWh}$ can be made with equation 8 .

$$
\Delta k W h_{a / c, \Delta l}=\alpha \Delta I A F_{\text {cond }} / C O P
$$

$\begin{array}{lll}\Delta k W h_{\mathrm{a} / \mathrm{c}, \Delta \mathrm{I}} & \text { increased a/c demand and energy savings from increase in incident sunlight } & \mathrm{kWh} \\ \alpha & \text { post period roof solar absorptance } & 0.30 \\ \Delta I & \text { increased incident sunlight } & k W h / \mathrm{ft}^{2} \\ A & \text { air-conditioned flat roof area } & 100,000 \mathrm{ft}^{2} \\ F_{\text {cond }} & \text { assumed fraction of solar roof load conducted to space } & 0.10 \\ C O P & \text { assumed a/c coefficient of performance } & 2.4 \mathrm{~kW} / \mathrm{kW}\end{array}$

Internal Gains Correction

Our model for estimating air-conditioning energy use assumed constant internal gains for pre- and postperiods, however there was a slight increase in non-air-conditioning demand of about $3.5 \mathrm{~kW}$ during the post period for the hours of 9 through 18. This increase is most likely attributable to a rise in internal lighting and/or plug loads. If it is entirely due to an increase in internal gains, then the following correction to the air-conditioning demand and daily energy savings can be made as shown in equation 9 . The estimate in air-conditioning demand savings can be increased by $1.5 \mathrm{~kW}$ (for a COP of 2.4) and the daily energy savings by $15 \mathrm{kWh}$ (for 10 hours).

$$
\Delta k W h_{a / c, \Delta I G}=\Delta I G / C O P
$$

$\begin{array}{llc}\Delta k W h_{a / c, \Delta \mathrm{IG}} & \text { increased air-conditioning savings from increase in internal gains } & k W h \\ \Delta I G & \text { increased internal gains } & k W h \\ C O P & \text { assumed a/c coefficient of performance } & k W / k W\end{array}$

A/C Annual Abated Energy and Demand Expenditures

Estimates of annual abated expenditures from air-conditioning energy savings and demand reduction are based on year 2000 commercial general service (E06) summer rates charged by Austin Energy (non- 
demand is $\$ 0.07 / \mathrm{kWh}$ and demand is $\$ 14 / \mathrm{kW} / \mathrm{month}$ ). The daily savings of $355 \mathrm{kWh}$ are an average for the months of August and September. These months have an average savings normalized for cooling degree-days of $18.9 \Delta \mathrm{kWh} /$ day per $\mathrm{CDD}_{65} /$ day, and this ratio applied for the entire year results in savings of $63 \mathrm{MWh}$ or about $\$ 4400$ in non-demand expenditures. The average demand reduction of $14 \%(35 \mathrm{~kW}$ for August and September) is booked once each month for the year and totals to $200 \mathrm{~kW}$ or $\$ 2800$ in reduced demand expenditures. Total $\mathrm{a} / \mathrm{c}$ annual abated non-demand and demand expenditures are estimated to be about $\$ 7200$ or $7.2 \phi / \mathrm{ft}^{2}$. Note, this estimate does not include any savings from taxes and other utility charges.

\section{Membrane Labor and Material Costs}

A discussion with the building owner's manager of roofing services revealed the following information. The owner's historical experience is to replace exposed black rubber membrane after 12 to 13 years of service with a white thermoplastic membrane. When changing out only the membrane system and leaving the existing insulation intact, thereby not increasing R-value, the cost in the Texas market is anticipated to be $\$ 1.50 / \mathrm{ft}^{2}$. The actual cost of membrane replacement (labor and materials) for this project was $\$ 1.52 / \mathrm{ft}^{2}$, in close agreement with the anticipated cost. As a generalization the building's manager indicated, when comparing costs between these two black and white membrane systems, the higher material cost for the white thermoplastic is offset against higher labor costs for installing a black rubber roof, resulting in a negligible cost differential.

\section{Membrane Service Life}

The owner's roofing manager further discussed service life of these two roofing systems. Expected service life for any roofing system is dependent upon a number of factors, the type, quality and thickness of materials, quality of installation workmanship, and environmental conditions and exposure to human traffic over the life of the roof. The roofing manager stated that the expected life of an exposed EPDM roofing system is approximately 13 years, within a range of 9 to 15 years. The service life for a white thermoplastic membrane ranges from 6 to 18 years and is heavily influenced by the formulation quality of the supplied materials. Thus, the roofing manager said it was fair to assume an expected service life of 13 years for each membrane system. The primary mode of failure for exposed EPDM roofing systems installed in the 1980's (this building was erected in 1987) is gradual degradation of seam adhesive, resulting in an increased frequency of nuisance leaks, and, for the thermoplastic membrane system it is the degradation of the plastisizer, resulting in membrane embrittlement and leaks associated with impact fractures.

\section{Simple Payback Period}

The simple payback was instantaneous with negligible incremental combined labor and material costs from replacing the black rubber with the white thermoplastic roof membrane.

\section{Present Value of Future Abated Energy Expenditures}

The present value of future abated energy expenditures is calculated from the present value multiplier $(\mathrm{PV}$ multiplier $)$, the roof surface albedo degradation factor $\left(\rho_{\mathrm{DF}}\right)$ and the estimated annual abated energy expenditures $\left(\Delta \$_{\text {abated }}\right)$ using equation 10 .

$$
\text { Present Value of Future Savings }=P V_{\text {multiplier }} \rho_{D F} \Delta \$_{\text {abated }}
$$

The PV multiplier is a function of the real discount rate (i) ${ }^{3}$ and the roof base-line service life ( $n$ ), equation 11. A base-line service life for the white thermoplastic membrane was chosen to be 13 years for the

\footnotetext{
3 The California Energy Commission (CEC) has adopted the real discount rate of $3 \%$ (i.e., in constant dollars after inflation) for energy-efficient buildings and other long-range investments designed to save fossil fuel for future generations.
} 
purpose of comparing benefits with the original black rubber membrane; the black roof lasted 13 years, so benefits were forecast over a similar time period 4 .

$$
\text { - } P V_{\text {multiplier }}=\left(1-(1+i)^{-n}\right) / i
$$

The solar reflectance (albedo) of a roof surface degrades over time, where a $10 \%$ to $20 \%$ degradation can be expected over several years. Hence, the albedo of the white membrane initially measured in the laboratory at 0.83 ( $\left.\rho_{\text {white_inital }}\right)$ can decrease to $0.75\left(\rho_{\text {white_aged }}\right)$ with $10 \%$ in degradation or to 0.66 with $20 \%$. The albedo of the aged black membrane was measured to be $0.05\left(\rho_{\mathrm{black}}\right)$. Therefore, the albedo degradation factor is calculated to be $0.90\left(\rho_{10 \% \mathrm{DF}}\right)$ or $0.78\left(\rho_{20 \% \mathrm{DF}}\right)$ using equation 12 .

$$
\rho_{D F}=\left(\rho_{\text {whit__aged }}-\rho_{\text {black }}\right) /\left(\rho_{\text {white_initial }}-\rho_{\text {black }}\right)
$$

With an estimated $\$ 7200$ in annual savings, the present value of future abated energy and demand expenditures range from $\$ 62,000$ to $\$ 71,000$ over the base-line 13 year service life of the roof membrane, assuming a 3\% real discount rate and a range in albedo degradation of $10 \%$ to $20 \%$.

\footnotetext{
4 Similar membranes from the same manufacturer of the reflective PVC membrane utilized in this project have a demonstrated service life in excess of 30 years internationally, 25 years domestically and 20 years in the state of Texas.

5 Bretz and Akbari (1997) have reported that the albedo of white-coated roof surfaces can degrade up to $20 \%$ over a period of several years as a result of weathering and accumulation of carbon, dirt and debris (microbial growth can contribute to degradation in humid climates) and by washing the roof the albedo can be restored to $90-100 \%$ of the initial value. Note, rainfall can cleanse a roof effectively and have the same effect as a thorough washing.
} 


\section{Conclusions}

In this study, we measured and documented air-conditioning (a/c) energy savings and demand reduction from a reflective roof membrane retrofit on a large retail store in Austin, Texas. This building was selected for two reasons. First, it was scheduled to have the original black rubber roof membrane, of 13 years, replaced with white thermoplastic (replaced during April and May 2000). Second, it was identified as a building with significant potential for a/c energy savings from a reflective roof; the white membrane, with such a large increase in solar reflectance compared to black (83\% to 5\%), tight plenum, moderate level of roof insulation (R-12hft $\left.{ }^{2 \circ} \mathrm{F} / \mathrm{Btu}\right)$, low efficiency air-conditioning equipment (rated EER at 8.6), seven days per week operation (9am to 9pm CST) and large conditioned roof area $\left(100,000 \mathrm{ft}^{2}\right)$.

The benefits from the reflective roof membrane on this building are numerous. Direct benefits include $a / c$ daily energy savings, a/c demand reduction, a/c annual abated energy and demand expenditures and present value of future savings. Benefits were calculated for the months of August and September and are highlighted below. In a mix of residential and commercial field-study buildings in California, Florida and Georgia, the roof-area weighted average of all a/c summertime daily energy savings measured was $3.2 \mathrm{Wh} / \mathrm{ft}^{2}$ and the reduced demand was $0.26 \mathrm{~W} / \mathrm{ft}^{2}$. By comparison, this large retail store yielded $3.6 \mathrm{Wh} / \mathrm{ft}^{2}$ in energy savings and $0.35 \mathrm{~W} / \mathrm{ft}^{2}$ in reduced demand.

1. A/C average summertime daily energy savings of $355 \mathrm{kWh}, 3.6 \mathrm{Wh} / \mathrm{ft}^{2}, 11 \%$ or $\$ 25$.

2. A/C average summertime demand (1-4pm) was reduced by $35 \mathrm{~kW}, 0.35 \mathrm{~W} / \mathrm{ft}^{2}, 14 \%$ or $\$ 490 /$ month.

3. A/C annual abated energy expenditures were $\$ 4400(63 \mathrm{MWh})$ and for demand they were $\$ 2800(200 \mathrm{~kW})$, totaling $\$ 7200$ or $7.2 \mathrm{e} / \mathrm{ft}^{2}\left(77 \mathrm{~d} / \mathrm{m}^{2}\right)$. Note, this estimate does not include savings from taxes and other utility charges.

4. Instantaneous payback. Negligible incremental combined labor and material costs from replacing the black rubber membrane with white thermoplastic, where the combined costs for both membranes were about $\$ 1.50 / \mathrm{ft}^{2}$.

5. Present value of future abated energy and demand expenditures is estimated to range from $\$ 62,000$ to $\$ 71,000$. Estimated with a real discount rate of $3 \%$, a base-line 13 year membrane service life and an aged white-membrane solar reflectance with $10 \%$ to $20 \%$ degradation from the initial value of 0.83 .

Additional benefits include participation in load curtailment and reflective roof rebate programs, and a decrease in roof surface and plenum air temperatures.

6. Participate in a load curtailment program. Austin Energy offers a Load Cooperative Program (Austin 2000a) which will make incentive payments consisting of two components to the customer for providing curtailable electric power between 1 June and 30 September: [1] Load Reduction Premium of $\$ 1.25 / \mathrm{kW}$ for average delivered $\mathrm{kW}$ of all curtailment sessions that have occurred during that calendar month, [2] Consumption Incentive of $\$ 0.15 / \mathrm{kWh}$ for all delivered $\mathrm{kWh}$ that month. If this retail building was in Austin Energy's Load Cooperative Program, a load reduction premium of $\$ 44$ would be payed for $35 \mathrm{~kW}$ in reduced demand for each curtailable session, and a consumption incentive of about $\$ 6300$ would be payed for saving 42MWh during the four month period.

7. Participate in a reflective roof rebate program. Austin Energy offers a Commercial Rebate Program (Austin 2000b) for reflective roofs. The existing roof must not be a reflective roof and the solar reflectance of the coating or single-ply membrane must have a minimum initial reflectance of $75 \%$. The rebate payment cannot exceed $50 \%$ of the total job cost, which includes equipment, installation and tax. If this retail building was in Austin Energy's Commercial Rebate Program, a maximum rebate on materials and labor of $\$ 0.75 / \mathrm{ft}^{2}$ or $\$ 75,000$ would be issued. 
8. Average summertime maximum roof surface temperature decreased by $42^{\circ} \mathrm{F}\left(168^{\circ} \mathrm{F}\right.$ to $126^{\circ} \mathrm{F}$ ). High temperature conditions accelerate the degradation in resistance of polyisocyanurate insulation, such as those with a black roof membrane. The owner's historical practice is to use more insulation (higher $\mathrm{R}$-value) to compensate for the decrease in $\mathrm{R}$-value, thus the additional layer of insulation is not necessary with a reflective roof.

9. Average summertime maximum plenum air temperature decreased by $6^{\circ} \mathrm{F}\left(101^{\circ} \mathrm{F}\right.$ to $\left.95^{\circ} \mathrm{F}\right)$. Since cables and electrical equipment are typically located in the plenum, the life of cable insulation increases in response to a reduced plenum air temperature. 


\section{References}

Akbari, H. and L. Rainer. 2000. "Measured Energy Savings from the Application of Reflective Roofs in 3 AT\&T Regeneration Buildings" Lawrence Berkeley National Laboratory Report LBNL-47075, Berkeley, CA.

Akbari, H., S. Bretz, D. Kurn and J. Hanford. 1997. "Peak Power and Cooling Energy Savings of HighAlbedo Roofs". Energy and Buildings 25:117-126.

Akridge, J. 1998. "High-Albedo Roof Coatings - Impact on Energy Consumption" ASHRAE Technical Data Bulletin 14(2).

ASTM Standard E1918-97. 1998. "Standard Test Method for Measuring Solar Reflectance of Horizontal and Low-Sloped Surfaces in the Field" Philadelphia, PA.

Austin Energy. 2000a. "Load Cooperative Agreement" Load Cooperative Program (512) 499-STAR, Austin, TX.

Austin Energy. 2000b. "Ceiling/Roof Insulation, Reflective Roof Coating Rebate Application" Commercial Rebate Program (512) 499-STAR, Austin, TX.

Boutwell, C. and Y. Salinas. 1986. "Building for the Future - Phase I. An Energy Saving Materials Research Project" Oxford: Mississippi Power Co., Rohm and Haas Co. and the University of Mississippi.

Bretz, S. and H. Akbari. 1997. "Long-Term Performance of High-Albedo Roof Coatings". Energy and Buildings 25: 159-167.

Hildebrandt, E., W. Bos and R. Moore 1998. "Assessing the Impacts of White Roofs on Building Energy Loads" ASHRAE Technical Data Bulletin 14(2).

Holman, J.P. 1984. "Experimental Methods for Engineers" p. 50. McGraw-Hill.

Konopacki, S., H. Akbari, L. Gartland and L. Rainer. 1998. Demonstration of Energy Savings of Cool Roofs". Lawrence Berkeley National Laboratory Report LBNL-40673. Berkeley, CA.

Parker, D. and K. Sheinkopf. 1999. "Cool Home Features Bring Peak Energy Savings" Home Energy. 16:22-27.

Parker, D., J. Huang, S. Konopacki, L. Gartland, J. Sherwin and L. Gu. 1998a. "Measured and Simulated Performance of Reflective Roofing Systems in Residential Buildings". ASHRAE Transactions 104(1):963-975.

Parker, D., J. Sherwin and J. Sonne. 1998b. "Measured Performance of a Reflective Roofing System in a Florida Commercial Building" ASHRAE Technical Data Bulletin 14(2).

Parker, D., J. Sonne and J. Sherwin. 1997. "Demonstration of Cooling Savings of Light Colored Roof Surfacing in Florida Commercial Buildings: Retail Strip Mall" Florida Solar Energy Center Report FSEC-CR-964-97, Cocoa, Fl. 



\section{Appendix}

\section{Roof Plan and Monitoring Equipment Location}

Figure A.1. Building roof plan identifies location of monitoring equipment and air-conditioning units.

\section{Load-Managed Operation}

Examination of the air-conditioning end-use load shapes and indoor air temperature profiles indicated a load-management strategy was implemented on seemingly random days following the retrofit, thus these data were discarded from the analysis. Analysis of load management is beyond the scope of this project. By comparing consecutive days, the first (30 August 2000) with load management and the second (31 August) without, Figure A.2 illustrates the linked behavior of the a/c power consumption and indoor air temperature. The figure clearly shows that the load-managed building is pre-cooled to $78^{\circ} \mathrm{F}$ between the hours of 8am and $11 \mathrm{am}$ in the morning, then between 11am and 12noon, the air-conditioning power is reduced by about $125 \mathrm{~kW}(50 \%)$ for a period of 15 to 45 minutes. The drop in a/c power directly corresponds to a rise in indoor air temperature from 78 to $80^{\circ} \mathrm{F}$, where the temperature remains for the day. This practice of pre-cooling and cutting the $\mathrm{a} / \mathrm{c}$ in half for 30 minutes, while it curtails peak load and flattens the load shape, it does add to the total daily energy usage. A comparison of these two days shows a peak curtailment of approximately $50 \mathrm{~kW}(17 \%)$, but a close to zero net savings in daily energy.

\section{5-Minute Monitored Data}

Figure A.3. Monitored 15-minute weather data for pre- and post-retrofit periods [outdoor air temperature, horizontal solar radiation, outdoor relative humidity, wind speed and direction].

Figure A.4. Monitored 15-minute roof system temperature data for pre- and post-retrofit periods [roof surface, roof underside, plenum air and indoor air].

Figure A.5. Monitored 15-minute power consumption data for pre- and post-retrofit periods [airconditioning $(\mathrm{a} / \mathrm{c})$, non-a/c and total building power].

\section{Statistics}

n: Number of observations.

prob>f: The probability of getting a greater $F$ statistic than that observed if the hypothesis is true. This is the significance probability.

$\sigma:$ Root MSE is an estimate of the standard deviation of the error term. It is calculated as the square root of the mean square error.

$\mathbf{R}^{2}$ : Is a measure between 0 and 1 that indicates the portion of the total variation that is attributed to the fit rather than left to residual error. It is also called the coefficient of determination and is the square of the correlation between the dependent variable and the predicted values.

Standard Error (SE): Standard deviation of the parameter estimate.

Uncertainty (W): Calculated from equations 13, 14, 15 and 16.(Holman 1984).

$$
\begin{gathered}
W_{k W h}=\left[\left[\frac{\partial k W h}{\partial C 0} W_{C 0}\right]^{2}+\left[\frac{\partial k W h}{\partial C 1} W_{C 1}\right]^{2}\right]^{1 / 2} \\
W_{k W h}=\left[\left[S E_{C 0}\right]^{2}+\left[\Delta T_{\text {mean }} S E_{C 1}\right]^{2}\right]^{1 / 2} \\
W_{\Delta k W h}=\left[\left[\frac{\partial \Delta k W h}{\partial C 0 p r e} W_{C 0 p r e}\right]^{2}+\left[\frac{\partial \Delta k W h}{\partial C 0 \text { post }} W_{C 0 p o s t}\right]^{2}\right]^{1 / 2} \\
W_{\Delta k W h}=\left[\left[S E_{C 0 p r e}\right]^{2}+\left[S E_{C \text { Opost }}\right]^{2}\right]^{1 / 2}
\end{gathered}
$$




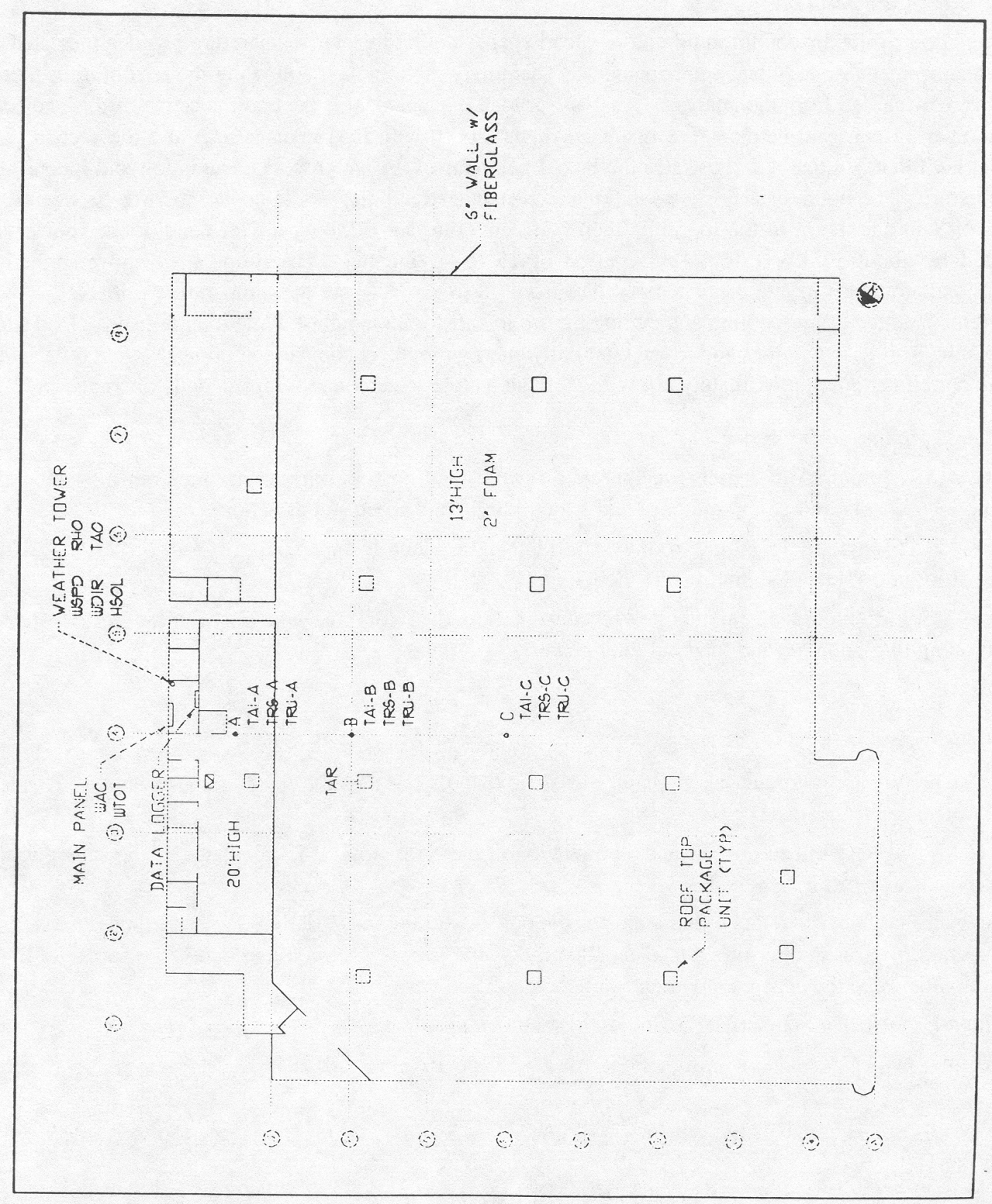

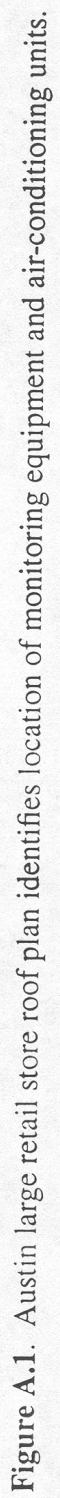




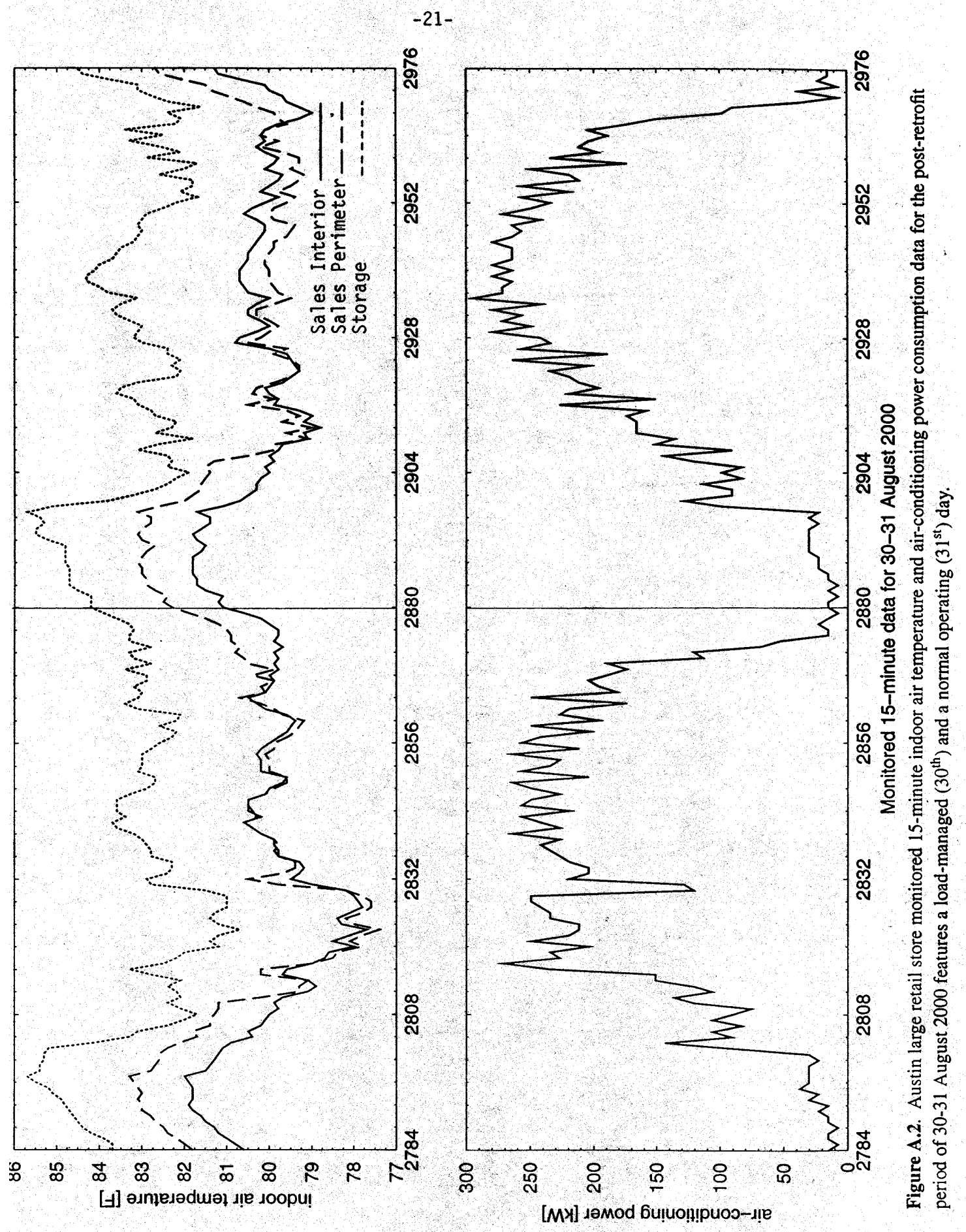




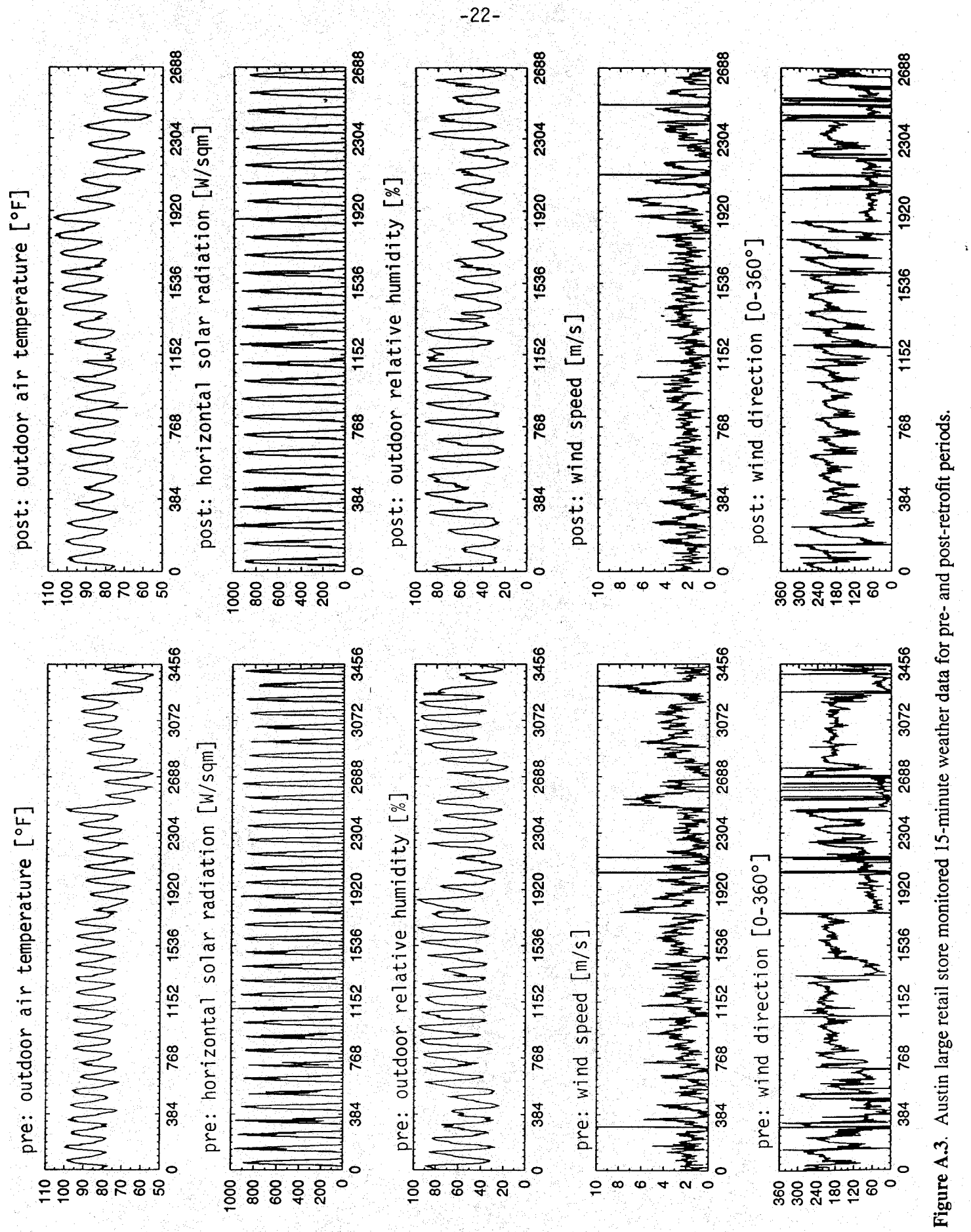



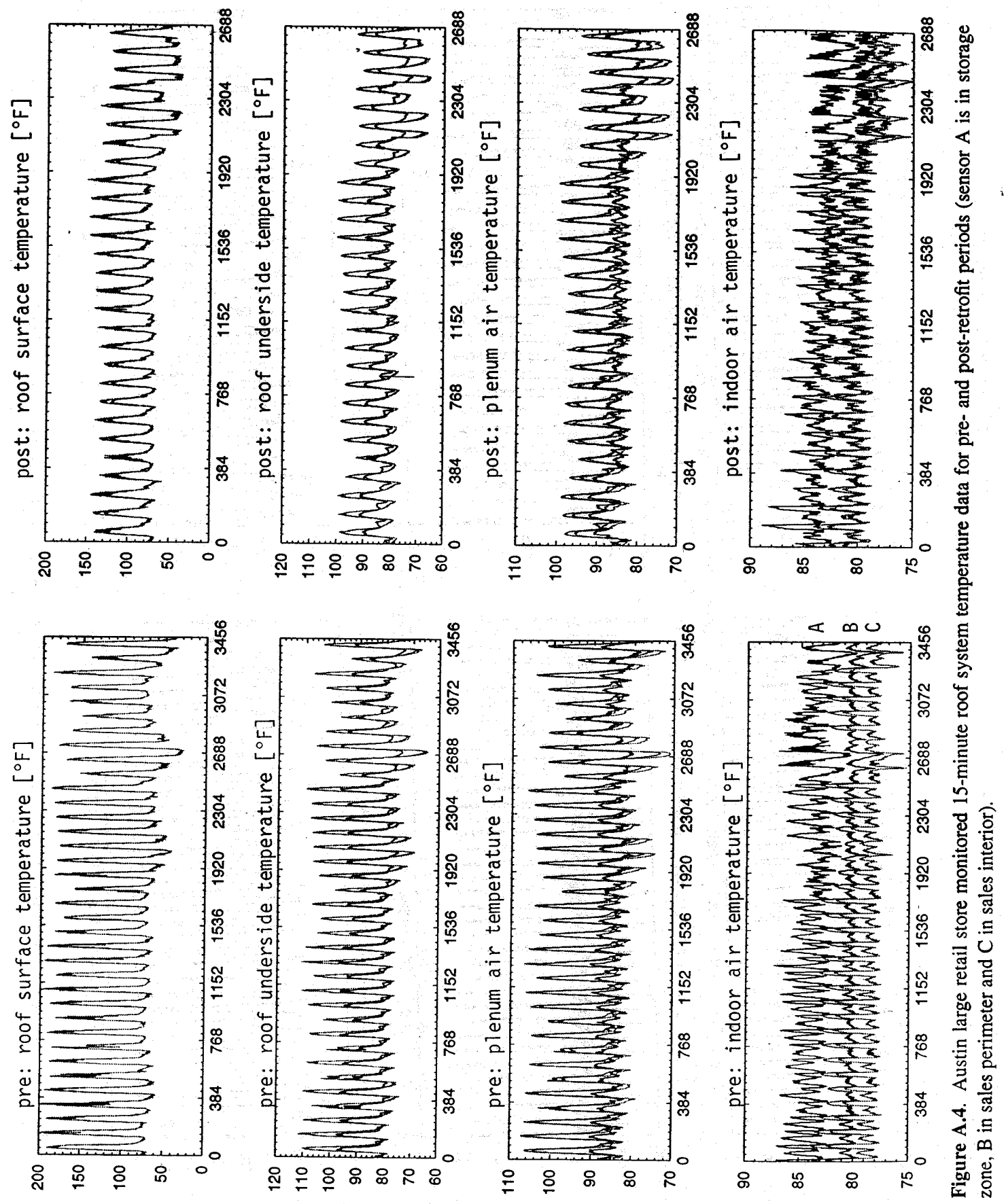
$-24-$
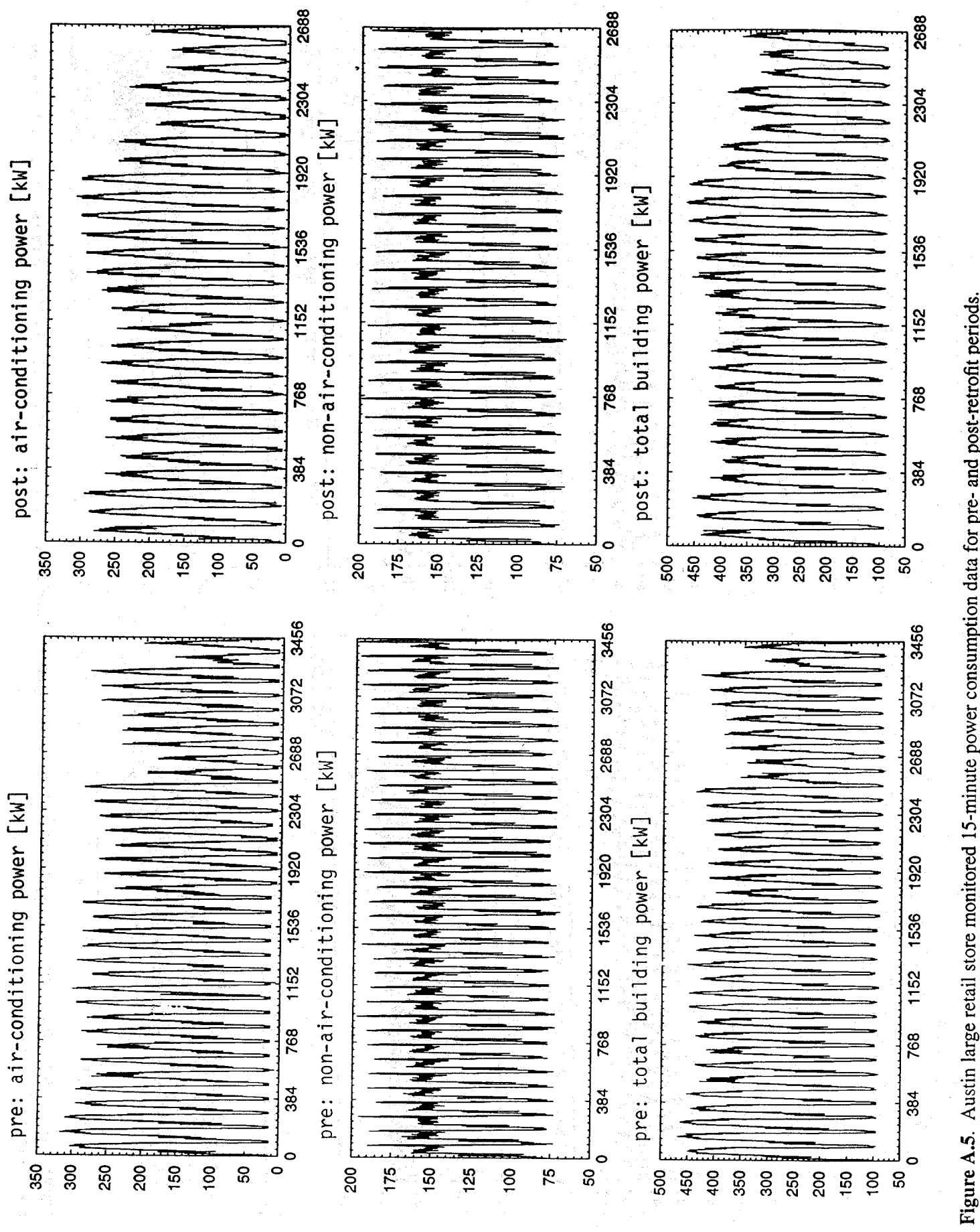
Table A.1. Single-variable regression analysis of variance, coefficients, standard error and uncertainty in model estimates of daily (hourly) air-conditioning energy use [kWh] versus the daily (hourly) difference between the outdoor and indoor air temperature $\left[T_{\text {out }}-T_{\text {in }}\right]$ for pre- and post-retrofit periods.

\begin{tabular}{|c|c|c|c|c|c|c|c|c|c|c|c|}
\hline \multirow{2}{*}{ hour } & \multicolumn{6}{|c|}{ analysis of variance } & \multicolumn{2}{|c|}{ coefficients } & \multicolumn{2}{|c|}{ standard error } & \multirow{2}{*}{$\begin{array}{c}\text { uncertainty } \\
\mathbf{k W h}\end{array}$} \\
\hline & $\mathbf{n}$ & prob $>f$ & $\boldsymbol{\sigma}$ & $\mathbf{R}^{2}$ & $\mathbf{k W h}$ mean & $\Delta \mathrm{T}_{\text {mean }}$ & $c_{0}$ & $c_{i}$ & $\mathrm{C}_{0}$ & $C_{1}$ & \\
\hline $\begin{array}{r}\text { pre } \\
1-24\end{array}$ & & 00001 & 184 & & 3159 & 0.56 & & & & & \\
\hline $1-24$ & 36 & 0.0001 & 184 & 0.93 & 3139 & 0.50 & 3090 & 114 & 30.8 & 5.52 & 31 \\
\hline 1 & $\begin{array}{l}36 \\
36\end{array}$ & 0.0001 & $\begin{array}{l}2.0 \\
1.6\end{array}$ & 0.70 & 15.4 & -5.44 & 18.4 & 0.54 & 0.5 & 0.06 & 1 \\
\hline 2 & 36 & 0.0001 & 1.6 & 0.81 & 15.7 & -7.00 & 19.8 & 0.58 & 0.4 & 0.05 & 1 \\
\hline 3 & 36 & 0.0001 & 4.4 & 0.63 & 17.2 & -8.26 & 26.1 & 1.08 & 1.4 & 0.14 & 2 \\
\hline 4 & 36 & 0.0001 & 13.7 & 0.73 & 48.7 & -9.16 & 86.8 & $4: 17$ & 4.6 & 0.43 & 6 \\
\hline 5 & 36 & 0.0001 & 15.3 & 0.78 & 90.5 & -9.22 & 137.9 & 5.14 & 5.0 & 0.47 & 7 \\
\hline 6 & 36 & 0.0001 & 14.8 & 0.76 & 77.2 & -9.13 & 118.2 & 4.48 & 4.6 & 0.43 & 6 \\
\hline 7 & 36 & 0.0001 & 10.2 & 0.82 & 97.4 & -8.01 & 124.9 & 3.44 & 2.8 & 0.28 & 4 \\
\hline 8 & 36 & 0.0001 & 12.3 & 0.65 & 96.7 & -6.38 & 113.5 & 2.64 & 3.0 & 0.34 & 4 \\
\hline 9 & 36 & 0.0001 & 12.3 & 0.80 & 118.5 & -2.90 & 129.9 & 3.92 & 2.3 & 0.34 & 3 \\
\hline 10 & 36 & 0.0001 & 15.5 & 0.81 & 148.6 & 0.45 & 146.4 & 4.96 & 2.6 & 0.41 & 3 \\
\hline 11 & 36 & 0.0001 & 15.4 & 0.89 & 181.0 & 3.53 & 158.1 & 6.51 & 2.9 & 0.39 & 3 \\
\hline 12 & 36 & 0.0001 & 12.8 & 0.94 & 208.1 & 6.12 & 163.3 & 7.32 & 2.9 & 0.33 & 4 \\
\hline 13 & 36 & 0.0001 & 11.5 & 0.94 & 226.0 & 7.88 & 171.4 & 6.93 & 3.1 & 0.31 & 4 \\
\hline 14 & 36 & 0.0001 & 15.8 & 0.88 & 240.2 & 9.40 & 172.7 & 7.18 & 4.9 & 0.45 & 6 \\
\hline 15 & 36 & 0.0001 & 15.3 & 0.88 & 247.0 & 10.27 & 176.5 & 6.86 & 5.1 & 0.43 & 7 \\
\hline 16 & 36 & 0.0001 & 17.1 & 0.84 & 245.4 & 10.79 & 172.6 & 6.75 & 6.1 & 0.50 & 8 \\
\hline 17 & 36 & 0.0001 & 14.6 & 0.89 & 234.9 & 10.77 & 158.1 & 7.13 & 5.2 & 0.43 & 7 \\
\hline 18 & 36 & 0.0001 & 16.2 & 0.86 & 218.0 & 9.90 & 152.7 & 6.59 & 5.3 & 0.46 & 7 \\
\hline 19 & 36 & 0.0001 & 18.3 & 0.79 & 190.0 & 7.69 & $146: 0$ & 5.72 & 4.9 & 0.50 & 6 \\
\hline 20 & 36 & 0.0001 & 15.5 & 0.82 & 162.9 & 4.91 & 136.9 & 5.29 & 3.3 & 0.42 & 4 \\
\hline 21 & 36 & 0.0001 & 13.8 & 0.84 & 144.3 & 2.57 & 131.5 & 4.98 & 2.5 & 0.38 & 3 \\
\hline 22 & 36 & 0.0001 & 10.6 & 0.77 & 93.2 & 0.60 & 91.3 & 3.22 & 1.8 & 0.30 & 2 \\
\hline 23 & 36 & 0.0001 & 5.0 & 0.68 & 26.7 & -1.97 & 29.2 & 1.28 & 0.9 & 0.15 & 1 \\
\hline $\begin{array}{r}24 \\
\text { post }\end{array}$ & 36 & 0.0001 & 1.8 & 0.77 & 15.1 & -4.01 & 17.5 & 0.59 & 0.4 & 0.05 & 0 \\
\hline $1-24$ & 28 & 0.0001 & 117 & 0.97 & 3222 & 4.37 & 2761 & 105 & 27.4 & 3.68 & 32 \\
\hline 1 & 28 & 0.0001 & 1.6 & 0.67 & 11.7 & -1.61 & 12.3 & 0.37 & 0.3 & 0.05 & 0 \\
\hline 2 & 28 & 0.0001 & 2.7 & 0.73 & 15.7 & -3.43 & 18.2 & 0.74 & 0.6 & 0.09 & 1 \\
\hline 3 & 28 & 0.0001 & 4.0 & 0.82 & 24.7 & -4.66 & 31.4 & 1.44 & 1.0 & 0.13 & 1 \\
\hline 4 & 28 & 0.0001 & 3.5 & 0.81 & 24.7 & -5.64 & 31.6 & 1.23 & 0.9 & 0.12 & 1 \\
\hline 5 & 28 & 0.0001 & 11.8 & 0.80 & 79.4 & -6.01 & 103.4 & 4.00 & 3.2 & 0.39 & 4 \\
\hline 6 & 28 & 0.0001 & 6.8 & 0.92 & 76.5 & -6.12 & 99.7 & 3.79 & 1.9 & 0.22 & 2 \\
\hline 7 & 28 & 0.0001 & 7.7 & 0.93 & 92.9 & -5.69 & 118.5 & 4.50 & 2.0 & 0.24 & 2 \\
\hline 8 & 28 & 0.0001 & 9.4 & 0.91 & 122.0 & -3.46 & 138.6 & 4.80 & 2.1 & 0.29 & 2 \\
\hline 9 & 28 & 0.0001 & 13.5 & 0.86 & 138.5 & 0.03 & 138.3 & 5.58 & 2.6 & 0.44 & 3 \\
\hline 10 & 28 & 0.0001 & 14.0 & 0.88 & 160.7 & 3.67 & 138.6 & 601 & 3.1 & 0.44 & 3 \\
\hline 11 & 28 & 0.0001 & 12.5 & 0.91 & 182.7 & 7.17 & 140.4 & 5.90 & 3.5 & 0.36 & 4 \\
\hline 12. & 28 & 0.0001 & 13.8 & 0.88 & 201.5 & 10.10 & 146.6 & 5.44 & 4.7 & 0.39 & 6 \\
\hline 13 & 28 & 0.0001 & 12.2 & 0.93 & 219.8 & 11.93 & 144.0 & 6.36 & 4.8 & 0.35 & 6 \\
\hline 14 & 28 & 0.0001 & 10.0 & 0.94 & 231.4 & 13.35 & 148.7 & 6.19 & 4.4 & 0.29 & 6 \\
\hline 15 & 28 & 0.0001 & 11.2 & 0.93 & 238.2 & 14.32 & 150.6 & 6.11 & 5.2 & 0.34 & 7 \\
\hline 16 & 28 & 0.0001 & 13.9 & 0.89 & 234.4 & 14.59 & 146.8 & 6.01 & 6.5 & 0.41 & 9 \\
\hline 17 & 28 & 0.0001 & 14.0 & 0,88 & 229.2 & 14.34 & 156.3 & 5.08 & 6.0 & 0.38 & 8 \\
\hline 18 & 28 & 0.0001 & 13.7 & 0.88 & 217.4 & 13.77 & 145.4 & 5.23 & 5.8 & 0.38 & 8 \\
\hline 19 & 28 & 0.0001 & 13.5 & 0.88 & 203.3 & 12.24 & 143.0 & 4.93 & 5.1 & 0.36 & 7 \\
\hline 20 & 28 & 0.0001 & 13.1 & 0.88 & 185.0 & 9.69 & 138.9 & 4.76 & 4.2 & 0.35 & 5 \\
\hline 21 & 28 & 0.0001 & 12.4 & 0.88 & 167.0 & 7.47 & 131.7 & 4.72 & 3.5 & 0.34 & 4 \\
\hline 22 & 28 & 0.0001 & 14.1 & 0.74 & 120.2 & 5.33 & 101.0 & 3.60 & 3.5 & 0.41 & 4 \\
\hline 23 & 28 & 0.0001 & 5.1 & 0.61 & 31.1 & 2.97 & 28.2 & 0.96 & 1.1 & 0.15 & 1 \\
\hline 24 & 28 & 0.0001 & 2.2 & 0.66 & 14.1 & 0.56 & 13.8 & 0.51 & 0.4 & 0.07 & 0 \\
\hline
\end{tabular}


Table A.2. Multi-variate regression analysis of variance, coefficients, standard error, model estimates and uncertainty of daily (hourly) air-conditioning energy use [kWh] versus the daily (hourly) difference between the outdoor and indoor air temperature $\left[\mathrm{T}_{\text {out }}-\mathrm{T}_{\text {in }}\right]$ for pre- and post-retrofit periods.

\begin{tabular}{|c|c|c|c|c|c|c|c|c|c|}
\hline hour & $\mathbf{n}$ & prob $>f$ & & $\begin{array}{l}\text { of } \\
R^{2}\end{array}$ & analysis of variance & $\Delta \mathrm{T}_{\text {mean }}$ & $\mathrm{C}_{\text {opre }}$ & $\begin{array}{l}\text { efficient } \\
C_{0 \text { nost }}\end{array}$ & $\mathrm{C}_{1}$ \\
\hline $\begin{array}{r}\text { pre \& post } \\
\text { daily }\end{array}$ & 64 & 0.0001 & 159 & - & 3187 & 223 & 3098 & 2743 & 110 \\
\hline 1 & 64 & 0.0001 & 1.9 & - & 13.8 & -3.77 & 17.9 & 12.4 & 0.46 \\
\hline & 64 & 0.0001 & 2.2 & - & 15.7 & -5.44 & 20.3 & 17.9 & 0.66 \\
\hline 3 & 64 & 0.0001 & 4.3 & $\therefore$ & 20.5 & -6.69 & 27.5 & 30.6 & 1.25 \\
\hline 4 & 64 & 0.0001 & 13.3 & - & 38.2 & -7.62 & 74.0 & 40.3 & 2.77 \\
\hline 5 & 64 & 0.0001 & 14.2 & - & 85.6 & -7.82 & 133.0 & 107.1 & 4.61 \\
\hline 6 & 64 & 0.0001 & 12.1 & - & 76.9 & -7.82 & 115.4 & 102.1 & 4.18 \\
\hline 7 & 64 & 0.0001 & 9.7 & - & 95.4 & -6.99 & 128.6 & 115.1 & 3.90 \\
\hline 8 & 64 & 0.0001 & 12.9 & - & 107.8 & -5.10 & 119.6 & 134.3 & 3.58 \\
\hline 9 & 64 & 0.0001 & 13.7 & - & 127.3 & -1.62 & 131.9 & 138.4 & 4.61 \\
\hline 10 & 64 & 0.0001 & 15.1 & - & 153.9 & 1.86 & 146,2 & 140.9 & 5.39 \\
\hline 11 & 64 & 0.0001 & 14.2 & - & 181.8 & 5.12 & 159.0 & 138.0 & 6.25 \\
\hline 12 & 64 & 0.0001 & 14.6 & - & 205.2 & 7.86 & 168.5 & 136.3 & 6.46 \\
\hline 13 & 64 & 0.0001 & 11.9 & - & 223.3 & 9.65 & 173.5 & 140,4 & 6.66 \\
\hline 14 & 64 & 0.0001 & 13.9 & - & 236.4 & 11.13 & 177.2 & 1419 & 6.71 \\
\hline 15 & 64 & 0.0001 & 13.7 & - & 243,1 & 12.04 & 180.1 & 145.0 & 6.51 \\
\hline 16 & 64 & 0.0001 & 15.8 & - & 240.6 & 12.45 & 176.6 & 141.3 & 6.38 \\
\hline 17 & 64 & 0.0001 & 15.7 & - & 232.4 & 12.33 & 170.2 & 143.0 & 6.01 \\
\hline 18 & 64 & 0.0001 & 15.7 & - & 217.7 & 1159 & 159.7 & 136.3 & 5.89 \\
\hline 19 & 64 & 0.0001 & 16.5 & $\therefore$ & 195.8 & 968 & 149.1 & 138.2 & 5.32 \\
\hline 20 & 64 & 0.0001 & 14.5 & $=$ & 172.6 & 7,00 & 138.2 & 136.3 & 5.02 \\
\hline 21 & 64 & 0.0001 & 13.2 & $=$ & 154.2 & 472 & 1318 & 130.7 & 4.85 \\
\hline 22 & 64 & 0.0001 & 12.2 & - & 105.0 & 2.67 & 91.1 & 102.1 & 3,41 \\
\hline 23 & 64 & 0.0001 & 5.1 & - & 28.6 & 0.19 & 28.9 & 27.8 & 1.12 \\
\hline 24 & 64 & 0.0001 & 2.0 & - & 14.7 & -2.01 & 17.3 & 13.8 & 0.55 \\
\hline
\end{tabular}

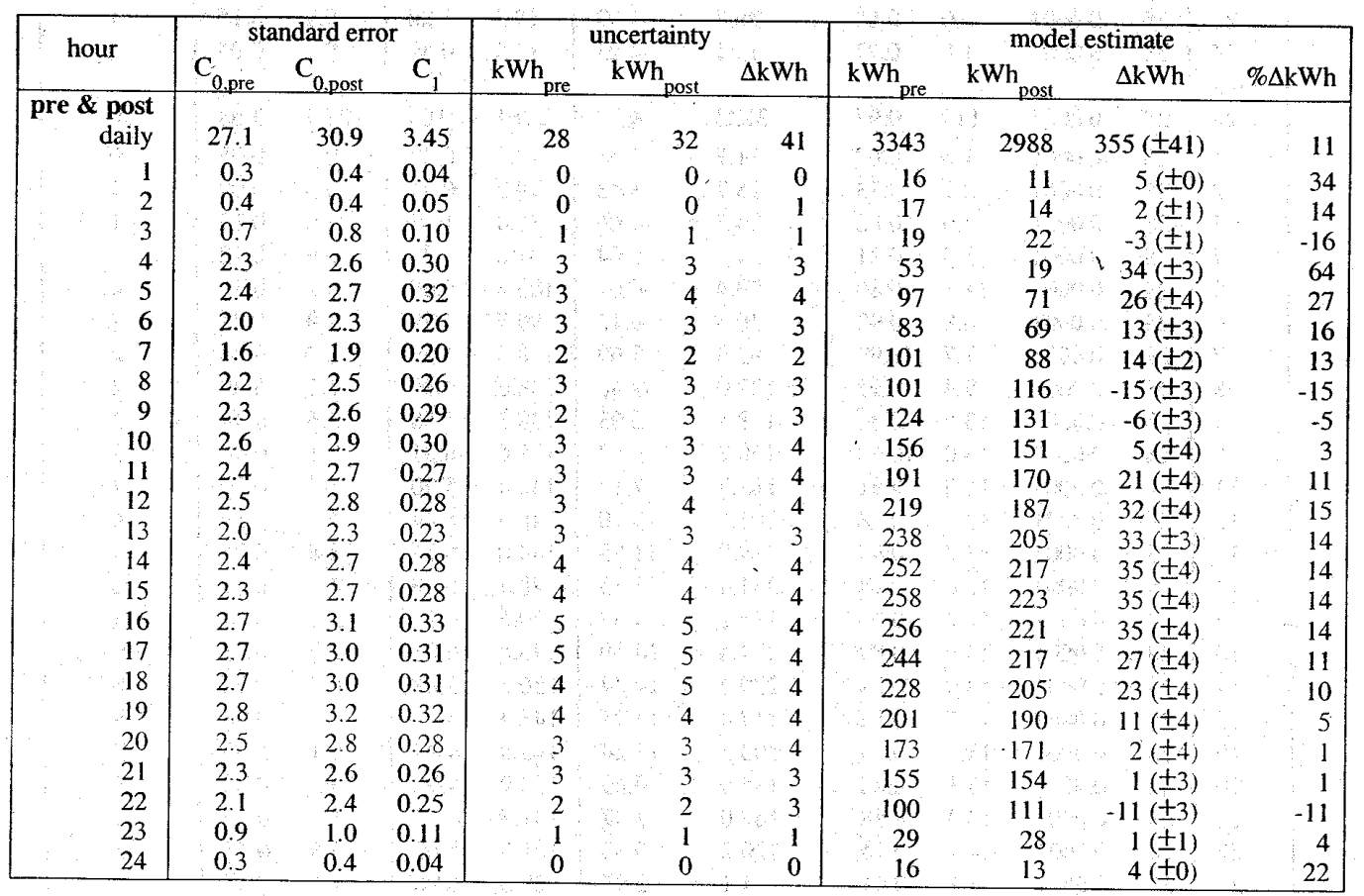

